\title{
The role of epigenetic mechanisms and processes in autoimmune disorders
}

\author{
This article was published in the following Dove Press journal: \\ Biologics:Targets and Therapy \\ 5 September 2012 \\ Number of times this article has been viewed
}

\author{
Judith M Greer \\ Pamela A McCombe \\ The University of Queensland, \\ UQ Centre for Clinical Research, \\ Brisbane, Queensland, Australia
}

Correspondence: Judith M Greer UQ Centre for Clinical Research, Bldg 71/918 Royal Brisbane and Women's Hospital, Herston, Brisbane QLD 4029, Australia

Tel +6I 733466018

Email j.greer@uq.edu.au
Abstract: The lack of complete concordance of autoimmune disease in identical twins suggests that nongenetic factors play a major role in determining disease susceptibility. In this review, we consider how epigenetic mechanisms could affect the immune system and effector mechanisms in autoimmunity and/or the target organ of autoimmunity and thus affect the development of autoimmune diseases. We also consider the types of stimuli that lead to epigenetic modifications and how these relate to the epidemiology of autoimmune diseases and the biological pathways operative in different autoimmune diseases. Increasing our knowledge of these epigenetic mechanisms and processes will increase the prospects for controlling or preventing autoimmune diseases in the future through the use of drugs that target the epigenetic pathways.

Keywords: twins, concordance, autoimmune disease, nongenetic factors, immune system, epigenetic modifications

\section{Epigenetics and epigenetic mechanisms What do we mean by "epigenetics"?}

"Epigenetics" can be broadly defined as events or processes that affect the inheritance of gene activities but do not depend on any changes in DNA base sequences. The activity of genes is dependent largely on whether they are accessible to transcription factors; this is highly regulated by the dynamics of chromatin restructuring. ${ }^{1}$ The basic repeating unit of chromatin is the nucleosome, in which $\sim 147$ base pairs of negatively charged DNA wrap 1.65 times around a highly positively charged histone protein octamer, consisting of the H2A, H2B, H3, and H4 histone subunits (Figure 1A). The nucleosomes compact further to form the $30 \mathrm{~nm}$ fiber, with the $\mathrm{H} 1 \mathrm{l}$ histone subunit playing an important role in stabilizing this structure. However, this tightly compacted chromatin structure poses barriers for processes such as transcription and replication, which require that the two strands of DNA come apart temporarily. Epigenetic "marks" on the chromatin play a central role in regulating the structure of chromatin (Figure 1B) and thus the accessibility of DNA for transcription. ${ }^{2}$

The actual term "epigenetics" was coined by CH Waddington in 1942 to describe the (at that stage, undefined) causal mechanisms by which the genes of a genotype could bring about phenotypic effects; ${ }^{3}$ for example, the process by which differentiated cells maintain their specialized phenotypes through repeated cell division, with some genes remaining permanently switched on and others permanently switched off, even though all cells of an organism carry the same complement of DNA, was labeled an "epigenetic" control system. ${ }^{4}$ It was not until the 1980 s, however, that 


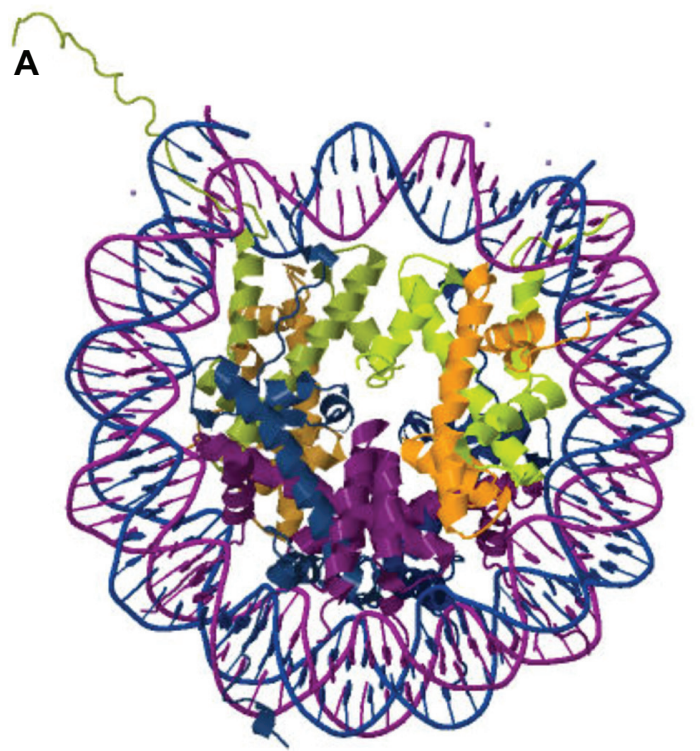

B

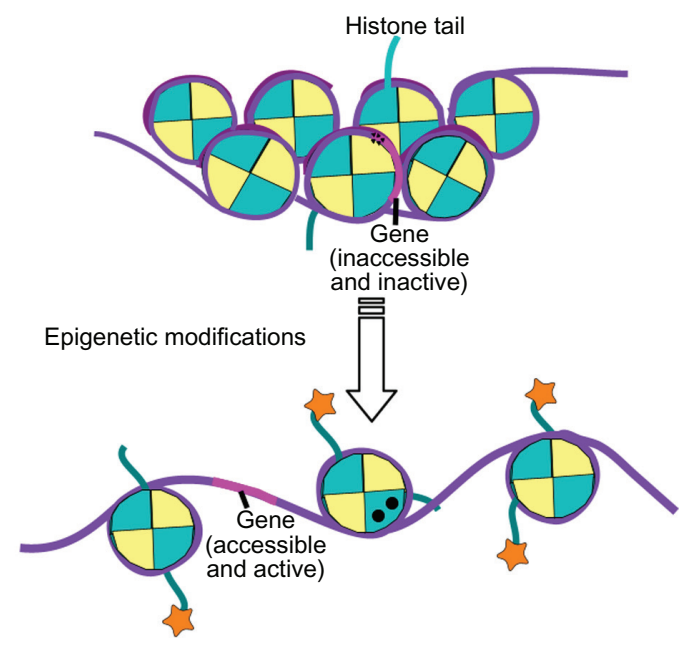

Figure I (A) Cartoon derived from the crystal structure (Protein Data Bank ID: Iaoi ${ }^{298}$ ) of the histone octamer (H2A, blue; H2B, purple; H3, green; H4, orange) surrounded by 1.65 turns of DNA ( 147 base pair fragment). (B) In compacted chromatin, genes (represented in pink) are inaccessible and inactive, with hypermethylation of their promoter regions ( $\mathbf{\Delta})$, and there are few posttranslational modifications to the histones. Epigenetic modifications in the form of demethylation of gene promoter region, posttranslational modification of the histones (ฌ), or swapping of histone subunits $(\varangle)$, lead to opening up of the chromatin. The gene is then accessible to transcription factors and RNA polymerase.

the term "epigenetics" was applied to a specific chemical modification, namely DNA methylation, that could affect the inheritance of gene activities without any changes in DNA base sequences. ${ }^{5}$ Subsequently, the epigenetic label has also been applied to many histone modifications and other chromatin modifications that regulate transcription and/or replication, ${ }^{6,7}$ including gene silencing and $\mathrm{X}$-inactivation, and to the regulatory actions of noncoding RNAs. ${ }^{8}$ Some investigators have argued that histone modifications per se are not epigenetic, ${ }^{9}$ as they have not been conclusively demonstrated to be self-propagating (heritable); however, as specific histone modifications can induce DNA methylation events, ${ }^{10,11}$ and DNA methylation events affect histone acetylation and histone methylation, there is an indirect heritability to these events. ${ }^{12}$ More recently, several authors have attempted to clarify the definition of epigenetics to encompass all that it has come to mean; $;^{13,14}$ in this paper we will take a fairly broad definition of "epigenetics" as modifications that do not involve DNA base changes, that play a central role in controlling tissue and signal-specific gene expression, and that are responsible for the determination of gene expression profiles of tissues and cellular subsets.

\section{Epigenetic modifications}

Epigenetic modifications act by changing the way that DNA and histones interact in the nucleus, thereby allowing or preventing access by transcription factors and RNA polymerases, and regulating gene expression. Understanding the processes by which the epigenetic modifications result in a specific outcome is a very topical area of research, but there are still some large gaps in the specifics of how some of these modifications exert their effects.

\section{DNA methylation}

DNA methylation is an important epigenetic modification and is of great interest to autoimmunity, as treatment with the DNA methylation inhibitor 5-azacytidine is sufficient to induce autoimmune disease in experimental animals. ${ }^{15,16}$ In mammals, DNA methylation typically involves the attachment of a methyl group to cytosine moieties in $\mathrm{CpG}$ dinucleotides (Figure 2) and occurs at $\sim 70 \%-80 \%$ of $\mathrm{CpG}$ sites throughout the genome. ${ }^{17}$ Methylated cytosine can be deaminated to thymine, either spontaneously or via enzymatic

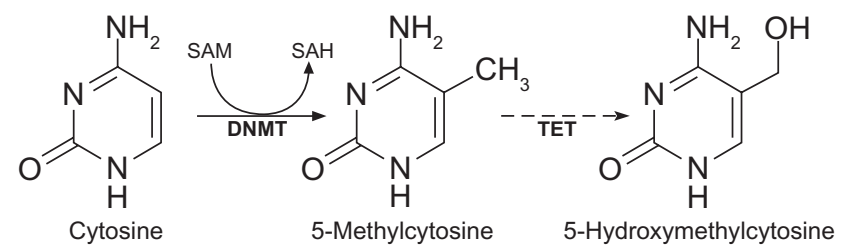

Figure 2 Methylation of cytosines in DNA.

Notes: In the presence of DNA methyl-transferases (DNMTs), methyl groups donated from S-adenosylmethionine (SAM) convert cytosine to 5-methylcytosine. 5-hydroxymethylcytosine can be generated by oxidation of 5-methylcytosine, via the action of the ten-eleven translocation (TET) family of enzymes.

Abbreviation: SAH, S-adenosylhomocysteine. 
processes, leading to an underrepresentation (less than a quarter of what would be expected) of $\mathrm{CpG}$ sequences in the genome. However, dense clusters of short ( $\sim 500 \mathrm{bp}) \mathrm{CpG}$-rich regions, known as "CpG islands," 18,19 also occur, particularly within the promoter region of genes, upstream from the transcriptional start sites (TSS), as many transcription factors require $\mathrm{CpG}$-rich sites to bind to DNA. ${ }^{20}$ The majority of CpG islands near TSS are hypomethylated; methylation of promoter $\mathrm{CpG}$ islands is usually linked to gene repression, ${ }^{12}$ although it is still not clear if methylation precedes compaction of the nucleosomes, or whether it might act to "lock" the compacted nucleosomes. ${ }^{21}$

Intragenic and intergenic $\mathrm{CpG}$ islands also occur and appear to be more susceptible to methylation than those in the promoter region. ${ }^{22}$ It is thought that intragenic $\mathrm{CpG}$ islands may in some instances represent alternative TSS that could, for example, be utilized in a highly tissue-restricted fashion. ${ }^{21,23}$ Furthermore, methylation in the gene body can silence repetitive DNA elements, such as retroviral elements and, in contrast to methylation in promoter regions, also appears to actively stimulate transcription elongation. ${ }^{19,21}$ The functional significance of intergenic $\mathrm{CpG}$ islands is as yet unclear, although studies have localized at least some of these to promoters of noncoding RNAs, ${ }^{24,25}$ suggesting they may help regulate expression of these molecules.

DNA methylation also appears to play regulatory roles outside of $\mathrm{CpG}$ islands. For example, recent studies on colon cancer have described DNA hypo- or hypermethylation of oncogenes or tumor repressors, respectively, at " $\mathrm{CpG}$ island shores," which lie up to $2 \mathrm{~kb}$ from $\mathrm{CpG}$ islands. ${ }^{26}$ Recently, there have been several reports of regions of the genome that have only $10 \%-50 \%$ of the typical amount of $\mathrm{CpG}$ methylation and that appear to be involved in binding of transcription factors or nuclear receptors (such as the glucocorticoid receptor) in a cell-type specific manner. ${ }^{27,28}$ The formation of these "low-methylated regions" (LMRs) has been found to significantly correlate with increased expression of the nearest gene, whereas remethylation of LMRs coincides with reduced expression; this suggests that these LMRs represent distal regulatory regions. ${ }^{27}$ Interestingly, 5-hydroxymethylcytosine (Figure 2), which is produced by oxidation of 5-methylcytosine, ${ }^{29}$ and TET1, which belongs to the family of ten-eleven translocation (TET) enzymes that catalyze this oxidative event, ${ }^{30}$ appear to both be enriched in LMRs, ${ }^{27}$ as 5-hydroxymethylcytosine has been reported to be present at enhancer regions, ${ }^{31,32}$ its enrichment in the LMRs provides support for the LMRs having a regulatory role.
Because DNA methylation plays such a critical role in regulating gene expression, the mechanisms for establishing, maintaining, and removing methyl groups have also been the subject of intense scrutiny, although there are still some major unanswered questions. DNA methylation of cytosines in mammalian cells occurs through the action of 5-methylcytosine DNA methyltransferases (DNMTs), which transfer a methyl group from a methyl group donor, S-adenosylmethionine, to the fifth carbon of the cytosine residues, converting them to 5-methylcytosines (Figure 2). Five DNMTs have been identified in mammalian cells. It was thought for some time that DNMT1 could, by itself, maintain patterns of DNA methylation during cell replication; however, it is now recognized that ongoing participation from DNMT3a and DNMT3b is also required for methylation maintenance. ${ }^{33}$ The latter are also critical for de novo methylation. ${ }^{34}$

It has been reported that DNA methylation can be very dynamic, with some genes undergoing cyclical changes within minutes to hours, ${ }^{35}$ but the mechanisms by which this type of rapid methylation/demethylation can occur are still not completely understood. Passive mechanisms of demethylation, such as occur when cells divide or when mammals erase genomic methylation patterns in primordial germ cells, are unlikely to account for such rapid cyclical changes in methylation patterns. However, the search for active demethylases has thus far not yielded very reproducible results. ${ }^{36}$ It is thought that the oxidation of 5-methylcytosine to 5-hydroxymethylcytosine via the action of TET family molecules may play a role in the more rapid cycles of methylation/demethylation, particularly in transcriptional regulatory regions such as enhancers. ${ }^{21,37}$

Initially, it was thought that methylation of $\mathrm{CpG}$ sites caused transcriptional repression by directly interfering with the binding of transcription factors to DNA; ${ }^{38}$ however, it now appears that this is not the main mechanism by which methylated DNA inhibits gene expression. Instead, the methylated DNA attracts proteins that contain a methylatedDNA binding domain (MBD) ${ }^{39,40} \mathrm{MBD}$-containing proteins provide links between methylated DNA and covalent and non-covalent histone modifications that act to modify chromatin and repress gene activity. ${ }^{41}$

\section{Histone modifications and chromatin remodeling}

Covalent modifications to the histone protein subunits can be made throughout the proteins; however, the $\mathrm{N}$-termini of the histones, which extrude from the tightly wound chromatin strands, are particularly susceptible 
to posttranslational modifications. Such modifications can include acetylation, methylation, ubiquitylation, phosphorylation, and SUMOylation. ${ }^{42}$ Acetylation/ deacetylation and methylation/demethylation appear to be of most importance in regulating gene expression. Acetylation (via the action of histone acetyltransferases) of selected lysine residues in the tails of nucleosomal histones removes the positive charge on the lysine amino group that is acetylated, loosening the interaction between DNA and the histone and preventing chromatin from folding into the $30 \mathrm{~nm}$ fiber; ${ }^{43}$ this typically promotes gene expression. ${ }^{44,45}$ In contrast, deacetylation (via histone deacetylases [HDACs]) is generally associated with gene repression. The phosphorylation state of histone $\mathrm{H} 1$ also appears to play a role in the folding of chromatin into higher-order structures. ${ }^{46}$ The effects on gene regulation of methylation of lysine or arginine residues in the histone tails depend on both the specific site of the modified residues in the histone tail and the number of methyl groups that are added to these residues. ${ }^{47,48}$ In some cases, the same amino acid of a histone tail can be either acetylated or methylated with varying consequences; for example, lysine at position 9 of histone $\mathrm{H} 3$ (H3K9) is acetylated in regions of the genome that are transcriptionally active, but methylated in areas that are transcriptionally silent. Other specific histone modifications with well-defined effects on gene expression include $\mathrm{H} 4$ hyperacetylation and trimethylation of $\mathrm{H} 3 \mathrm{~K} 4$, both of which are present in many active genes. ${ }^{49}$ Common sites of posttranslational histone modifications in $\mathrm{H} 3$ and $\mathrm{H} 4$ are shown in Table 1, although not all of these are necessarily epigenetic - some will probably be of more relevance to DNA replication and repair.

Acetylation of lysine and methylation of lysine or arginine on histone tails plays a role in orchestrating the recruitment of multiprotein complexes. Some components of these complexes can "read" the histone changes via molecular interactions of the methyl/acetyl chains with structurally conserved protein modular domains that are present in many chromatin regulators and transcription factors and that act to change chromatin structure at target gene loci. ${ }^{50}$ Some of these "readers" are extremely versatile: for example, proteins containing plant homeodomain (PHD) fingers appear to be able to read histone states in a sequence-dependent manner that is modulated positively or negatively by the methylation state of lysine and arginine, as well as by the acetylation state of lysine (reviewed in Sanchez and Zhou ${ }^{51}$ ). Other components of the protein complexes recruited by the histone modifications are involved in chromatin remodeling: these components contain a conserved ATPase domain. ${ }^{52}$
Remodeling utilizes energy from ATP hydrolysis to mobilize and restructure the nucleosomes and/or replace the histones themselves with histone variants. ${ }^{52,53}$ For example, remodeling complexes of the SWR1 family can replace $\mathrm{H} 2 \mathrm{~A}$ histones in H2A-H2B dimers with H2A.Z, forming variant nucleosomes with unique histone tails that can potentially bind unique regulatory proteins. ${ }^{54}$ Other remodelers enable movement of nucleosomes along the DNA, thereby exposing new DNA to regulatory factors. Exactly how remodelers mobilize the nucleosome and how different remodeler complexes select which nucleosomes to move and restructure is still imperfectly understood.

\section{Noncoding RNAs}

Around $98 \%$ of the transcribed human genome does not encode proteins ${ }^{55}$ and recent studies have identified several different types of noncoding RNAs that act posttranscriptionally to regulate many biological processes via their interactions with messenger RNA (mRNA) or DNA. ${ }^{16,56,57}$ Currently, those thought to be of most relevance to autoimmunity are the microRNAs (miRNAs) and long noncoding RNAs (IncRNAs), although it is likely that further investigation will find that at least some of the other noncoding RNA types are also important.

The miRNAs are small molecules of around 22 nucleotides in length, which are believed to regulate the translation of more than $60 \%$ of protein-coding genes. ${ }^{57,58}$ In humans, more than 1000 miRNAs have been identified. ${ }^{56,59}$ Translation of mRNA into protein is blocked by human miRNAs primarily by inhibition of translation initiation either via binding of the miRNAs to the $3^{\prime} \mathrm{UTR}^{57}$ or (less frequently in humans) via induction of mRNA degradation. ${ }^{60}$ Some miRNAs regulate specific individual targets, while others appear to function as master regulators of a process, regulating expression levels of hundreds of genes simultaneously. ${ }^{56,57,61}$ Recent studies suggest that there is strong bidirectional regulation between specific miRNAs and HDACs. For example, downregulation of miR-9 in bone marrow-derived CD19+ cells from patients with the B-cell lymphoma Waldenström's macroglobulinemia results in upregulation of HDAC4 and HDAC5 expression levels and aberrant histone acetylation in these cells, and leads to abnormal expression of genes that cause the lymphoma. ${ }^{62}$ Conversely, HDACs that are overexpressed in chronic lymphocytic leukemia block critical apoptosis-related miRNAs in the malignant B cells, resulting in pro-survival signals. ${ }^{63}$

A fast-expanding area of research involves the role of lncRNAs in epigenetics. The definition of lncRNAs is complicated by the observation that IncRNAs often overlap with, or are 
Table I Posttranslational modifications to tails of histones $\mathrm{H} 3$ and $\mathrm{H} 4$

\begin{tabular}{|c|c|c|c|c|}
\hline Position & Amino acid* & $\begin{array}{l}\text { Posttranslational } \\
\text { modification }\end{array}$ & $\begin{array}{l}\text { Site where active } \\
\text { (if known)** }\end{array}$ & $\begin{array}{l}\text { Likely outcome on transcriptional } \\
\text { state of chromatin (if known) }\end{array}$ \\
\hline \multicolumn{5}{|c|}{ Histone H3 } \\
\hline 2 & $\mathrm{R}$ & Methylation & GB & \\
\hline 3 & $\mathrm{~T}$ & Phosphorylation & & \\
\hline \multirow[t]{4}{*}{4} & $\mathrm{~K}$ & Mono-methylation & $E, P$ & Activation \\
\hline & & Di-methylation & $E, P$ & Activation \\
\hline & & Tri-methylation & $P$ & Activation $>$ repression \\
\hline & & Acetylation & $P$ & Activation \\
\hline 8 & $\mathrm{R}$ & Methylation & & \\
\hline \multirow[t]{4}{*}{9} & $\mathrm{~K}$ & Mono-methylation & $\mathrm{P}$ & Activation \\
\hline & & Di-methylation & $\mathrm{E}, \mathrm{GB}$ & Repression \\
\hline & & Tri-methylation & $E, G B, P$ & Repression \\
\hline & & Acetylation & $\mathrm{P}$ & Activation \\
\hline 10 & $S$ & Phosphorylation & & \\
\hline 14 & K & Acetylation & & Activation \\
\hline 17 & $\mathrm{R}$ & Methylation & & ? Activation \\
\hline 18 & $\mathrm{~K}$ & Acetylation & $\mathrm{P}$ & Activation \\
\hline 23 & $\mathrm{~K}$ & Acetylation & $\mathrm{GB}, \mathrm{P}$ & Activation \\
\hline 26 & $\mathrm{R}$ & Methylation & & \\
\hline \multirow[t]{4}{*}{27} & K & Mono-methylation & GB & Activation \\
\hline & & Di-methylation & GB & Repression \\
\hline & & Tri-methylation & $\mathrm{P}$ & Repression $>$ activation \\
\hline & & Acetylation & E, LMR, P & Activation \\
\hline 28 & $S$ & Phosphorylation & & \\
\hline \multirow[t]{2}{*}{36} & $\mathrm{~K}$ & Tri-methylation & GB & Activation \\
\hline & & Acetylation & $P$ & Activation \\
\hline 56 & K & Acetylation & & Activation \\
\hline \multirow[t]{3}{*}{79} & $\mathrm{~K}$ & Mono-methylation & GB & Activation \\
\hline & & Di-methylation & GB & Activation \\
\hline & & Tri-methylation & GB & Activation or repression \\
\hline \multicolumn{5}{|c|}{ Histone H4 } \\
\hline I & $\mathrm{S}$ & Phosphorylation & & \\
\hline 3 & $\mathrm{R}$ & Methylation & GB & \\
\hline 5 & K & Acetylation & $\mathrm{P}$ & Activation \\
\hline 8 & K & Acetylation & $P$ & Activation \\
\hline 12 & K & Acetylation & $P$ & Activation \\
\hline 16 & K & Acetylation & $P$ & Activation \\
\hline \multirow[t]{2}{*}{20} & $\mathrm{~K}$ & Mono-methylation & $\mathrm{P}$ & Activation \\
\hline & & Tri-methylation & GB & Repression \\
\hline
\end{tabular}

Notes: *Single-letter amino acid code: $\mathrm{K}$, lysine; $\mathrm{R}$, arginine; $\mathrm{S}$, serine; $\mathrm{T}$, threonine. **Information in this table has been assembled from references $23,48,50$, and $228-234$. ? indicates that this modification probably leads to activation, but it is not yet proven.

Abbreviations: E, enhancer; GB, gene body; LMR, low-methylated region; P, promoter.

interspersed between, multiple coding and noncoding transcripts; however, typically, they are more than 200 nucleotides in length and probably make up the largest portion of the mammalian noncoding transcriptome. ${ }^{64}$ The $\operatorname{lncRNAs}$ appear to be able to recruit chromatin remodeling complexes to specific $\operatorname{loci}^{65}$ and to regulate gene expression at the level of both transcription ${ }^{66,67}$ and posttranscriptional processing. ${ }^{64,68}$

\section{Intersection of epigenetic pathways: $X$ marks the spot}

One of the best known processes where the various epigenetic pathways and mechanisms intersect is in the regulation of the
X chromosome: normal females possess two X chromosomes and, in any given cell, one chromosome will be active (Xa) and one will be inactive (Xi), ${ }^{69}$ whereas, in normal males, the $\mathrm{X}$ chromosome will remain active. However, during reproduction in mammals, the $\mathrm{X}$ chromosome undergoes its own cycle of inactivation and reactivation. The paternally derived $\mathrm{X}$ chromosome $\left(\mathrm{X}^{\mathrm{P}}\right)$ is imprinted in pre-implantation female embryos, leading to $\mathrm{X}^{\mathrm{P}}$ inactivation. ${ }^{70}$ At implantation, the $\mathrm{X}^{\mathrm{P}}$ is reactivated and then, in the embryo proper (when there are $\sim 80-120$ cells), X chromosome inactivation occurs randomly in each cell of the embryo, ${ }^{71}$ so that all cells derived from each of these initial cells will maintain the same $\mathrm{X}$-inactivation 
pattern. Thus, females are mosaics of two cell populations with respect to $\mathrm{X}$-linked gene expression, one expressing the paternally derived genes and one expressing the maternally derived genes.

The X-inactivation center on each X chromosome contains the $17 \mathrm{~kb}$ lncRNA, X-inactivation specific transcript (Xist), which is necessary and sufficient for inactivation of the chromosome. ${ }^{72,73}$ Xist is involved in the transient imprinting of the $\mathrm{X}^{\mathrm{P}}$ during embryogenesis. ${ }^{74,75}$ In addition, during the inactivation process, the future Xi dramatically increases Xist RNA production and the Xist RNA spreads out from the $\mathrm{X}$-inactivation center to progressively coat the chromosome; ${ }^{73}$ in contrast, the future Xa ceases to express Xist. The silencing of genes along the Xi occurs soon after coating by Xist RNA; Xist appears to be crucial for initiating silencing but has a minor role in maintaining the $\mathrm{Xi}$. Silence is maintained by packaging the $\mathrm{Xi}$ into densely packed, transcriptionally inactive heterochromatin, and is associated with high levels of DNA methylation, low levels of histone acetylation, low levels of histone H3K4 and H3R17 methylation, and high levels of histone H3K9 methylation. ${ }^{76}$ Additionally, variants of histone $\mathrm{H} 2 \mathrm{~A}$ are exclusively found on nucleosomes along the $\mathrm{Xi} .{ }^{76}$ Thus, multiple layers of epigenetic modifications are involved in the process of $\mathrm{X}$ chromosome inactivation and silencing and they operate cooperatively to regulate gene expression. Given the predominance of autoimmunity in females, ${ }^{77-79}$ it is pertinent to question whether some of these mechanisms may fail in autoimmunity. This will be discussed in subsequent sections.

\section{Studies of monozygotic (MZ) twins support a role for epigenetics in the development of autoimmunity}

The etiology of the majority of autoimmune diseases remains obscure; however, for most, it appears that disease arises because of immune-, gene-, and environment-related effects. Evidence from studies of $\mathrm{MZ}$ twins shows that the penetrance of autoimmunity is typically in the order of only $20 \%-30 \%$ (Table 2), suggesting that a particular DNA nucleotide sequence alone is not sufficient for development of disease. For some of these diseases, widely varying concordance rates have been reported; it appears that factors such as the latitude of the country where the study participants lived ${ }^{80,81}$ and the age of disease onset in the proband ${ }^{80}$ can influence the concordance rate, suggesting that environment and aging are major modifiers of the purely genetic effects. In addition, the number of years after diagnosis (in the proband) that the study was done appears also to be a determining factor in the concordance rate. For example, when MZ twin pairs initially discordant for type 1 diabetes (T1D) were followed over many years, the percentage of the initially unaffected twins who subsequently developed T1D increased at a slow rate until the age of 40 , but then jumped from $25 \%$ at 40 years of age to over $60 \%$ at 60 years of age, ${ }^{82}$ suggesting that, during the fifth or sixth decades of life, external and/or internal changes negate the protective effect that has prevented the initially healthy twin from developing disease up until that point. This would be most consistent with a role for epigenetic effects as modifiers of autoimmune disease penetrance, although clonal mosaicism that increases with age may also play a role..$^{83,84}$

To investigate the role of epigenetics, several studies have looked at whether there are differences in DNA methylation in $\mathrm{MZ}$ twins discordant for autoimmune disease. The evidence is variable. Javierre et $\mathrm{l}^{85}$ found DNA methylation changes in $\mathrm{MZ}$ twins discordant for systemic lupus erythematosus (SLE), but not for rheumatoid arthritis (RA) or dermatomyositis. In studies of female twin pairs discordant for multiple sclerosis (MS), Baranzini et $\mathrm{al}^{86}$ found few differences between female $\mathrm{MZ}$ twin pairs with respect to either DNA sequences, DNA methylation, or RNA sequences;

Table 2 Autoimmune diseases, showing female:male ratios of patients and concordance rates in monozygotic (MZ) twins

\begin{tabular}{|c|c|c|c|}
\hline Disease & Target & Female:male ratio & Concordance in MZ twins \\
\hline Multiple sclerosis & Central nervous system myelin & $1.9-4.3:\left.\right|^{140,235,236}$ & $14 \%-33 \%^{81,237-240}$ \\
\hline Type I diabetes mellitus & Beta-islet cells of the pancreas & $0.5-0.8: 1^{241,242}$ & $\begin{array}{l}\text { I3\%-60\% } \\
\text { genotype; }{ }^{244} \text { latitude } 245 \text { affected by insulin }\end{array}$ \\
\hline Systemic lupus erythematosus & Cell nucleus & $8.7-13.1: 1^{246}$ & $11 \%-33 \%^{85,247-249}$ \\
\hline Rheumatoid arthritis & Joints & $2.7: 1^{250}$ & $12 \%-15 \% 251-253$ \\
\hline Graves' disease & Thyroid & $3.5: 1^{254}$ & $17 \%-35 \% 255,256$ \\
\hline Primary biliary cirrhosis & Liver & $9: 1^{257}$ & $63 \%^{258}$ \\
\hline Psoriasis & Skin & $0.8-||:.\left.\right|^{242,259}$ & $35 \%-70 \%{ }^{260,261}$ \\
\hline Myasthenia gravis & Acetylcholine receptors & $2: 1^{262}$ & $35 \%^{263}$ \\
\hline Ankylosing spondylitis & Joints & $1: 3^{264}$ & $40 \%-80 \% 265$ \\
\hline
\end{tabular}


however, because only extreme methylation differences (a change of at least 60\%) were investigated in this study, and only far smaller differences have been identified in some other studies using nonmalignant tissues, ${ }^{87-89}$ potential variation could have been missed. In MZ twin pairs discordant for psoriasis, differences in DNA methylation between unaffected and affected twins were correlated with differences in gene expression, particularly in $\mathrm{CD} 4^{+} \mathrm{T}$ cells..$^{90} \mathrm{~A}$ recent study looked for methylation differences in CD14+ monocytes from MZ twin pairs discordant for T1D and identified 132 different $\mathrm{CpG}$ sites at which the direction of the intra-MZ pair DNA methylation difference significantly correlated with the diabetic state. ${ }^{91}$ Of course, DNA methylation is not the only epigenetic change that might explain the lack of concordance in $\mathrm{MZ}$ twin pairs, but as yet there are few studies investigating other potential mechanisms. Furthermore, most of these studies only investigated small numbers of twin pairs and most used peripheral blood containing multiple cell types (and therefore multiple epigenomes) as the source of DNA, which could skew methylation differences, ${ }^{92}$ making it difficult to draw global conclusions from the results.

\section{Evidence for epigenetic modifications in autoimmune diseases}

Each autoimmune disease involves at least two major players, the immune system, which is the effector of the autoimmune damage, and the target organ, which can have variable degrees of resistance to autoimmune damage. Epigenetic modifications to either the immune system or the target organ could play a role in disease development. In the following section, we will review some of the modifications that have been found thus far, but major questions remain unanswered, such as: Are the same epigenetic modifications seen in all patients with the same clinical phenotype? How do the epigenetic effects interact with polymorphisms in autoimmune susceptibility genes? Is there a threshold in the number/type of epigenetic modifications that need to occur for disease to become manifest?

\section{Epigenetic modifications in the immune system}

Numerous recent studies clearly indicate that there is epigenetic control of major immune cell functions, such as hematopoietic lineage choice, antigen-receptor rearrangement and allelic exclusion, and immune responses to pathogens. ${ }^{93-105}$ For example: epigenetic processes govern the differentiation of Thelper cells and their lineage stability, ${ }^{93,105}$ exposure of dendritic cells to oxidized phospholipids can change the phenotype of the cells through epigenetic mechanisms, ${ }^{106}$ and epigenetic processes control the production of antibodies by B cells. ${ }^{107}$ These immunological developmental events that are regulated by epigenetic mechanisms could possibly be altered to promote autoimmunity. In this section, we will focus on some of the epigenetic modifications that could specifically affect susceptibility to, or development of, autoimmune diseases.

\section{Epigenetic control of immune tolerance}

One of the major mechanisms in the control of development of autoreactive immune cells is induction of $\mathrm{T}$ cell central tolerance in the thymus. Central tolerance against many autoantigens is regulated by the autoimmune regulator (AIRE) protein, which promotes expression of tissue-specific antigens in thymic medullary epithelial cells. AIRE contains PHD fingers, which bind to methylated histone $\mathrm{H} 3$ and provide a link between the status of histone modifications and the regulation of tissue-specific antigen expression in the thymus. In an animal model with a targeted mutation within one of these PHD fingers, there was decreased binding of AIRE to methylated histone $\mathrm{H} 3$, a generalized dampening of AIRE's transcriptional impact, and development of autoimmunity. ${ }^{108}$

Another potential mechanism by which epigenetic mechanisms could affect central tolerance is via the action of the lncRNA, growth-arrest-specific 5 (GAS5). GAS5 sensitizes cells to apoptosis by regulating the activity of glucocorticoids, is present in T cells, ${ }^{109}$ and has been linked to increased susceptibility to autoimmune disorders, including SLE. ${ }^{110}$ Positive selection of T cells in the thymus is postulated to be dependent on the counter-interaction between glucocorticoid receptor- and $\mathrm{T}$ cell receptor-induced death signals. ${ }^{111}$ Modulation of GAS5 expression levels could regulate selection of $\mathrm{T}$ cells through the glucocorticoid receptor, thereby providing resistance to apoptosis, allowing escape of self-reactive T cells, and potentiating development of autoimmunity.

There is evidence that miRNAs also play a major role in induction of central tolerance. For example, the affinity of maturing $\mathrm{T}$ cells for antigen during thymic development plays a large role in determining their fate: there appears to be a strong correlation between the sensitivity of the $\mathrm{T}$ cells to antigen and levels of miR-181a, which is dynamically regulated during $\mathrm{T}$ cell maturation in the thymus. ${ }^{112}$ In addition, recent studies have identified a selection of miRNAs that have known functions in thymopoiesis and which are differentially regulated in the thymus following stress; this 
dysregulation has the potential to alter $\mathrm{T}$ cell repertoire selection and the formation of naive T cells. ${ }^{113}$

In the periphery, some of the best-studied mediators of tolerance are the $\mathrm{CD}^{+}{ }^{+}$Foxp $3^{+}$regulatory $\mathrm{T}$ cells (Tregs). Foxp3 is known to form complexes with histone acetyltransferases (Tip60 and p300) or HDACs (HDAC7); these complexes then epigenetically modulate target gene expression via histone or Foxp3 acetylation or deacetylation. ${ }^{14,115}$ Recently, it was shown that mice in which Foxp3 failed to associate with Tip60 and HDAC7 had altered Foxp3-dependent transcription and epigenetic modifications, causing insufficiency in natural Tregs and impaired development of inducible Tregs. ${ }^{116}$ It has been reported that Foxp3 also represses the activity of SATB1, a genome organizer that regulates chromatin structure and gene expression, leading to loss of suppressive function in the Tregs and establishment of effector functions. ${ }^{117}$ Foxp3 not only acted directly as a transcriptional repressor of SATB1 but also indirectly through the induction of miRNAs that bind the SATB1 3' untranslated region. Other studies have also highlighted the role that miR-155 plays in Treg development and that miR-146 and the miR-17-92 cluster play in Treg function (as recently reviewed in Zhou et al, 2011). ${ }^{118}$

Other cells involved in maintenance of peripheral tolerance include natural killer $\mathrm{T}$ cells and regulatory subsets of dendritic cells. Several reports of miRNA- or HDACmediated regulation of these subsets of cells exist, although most have not specifically addressed the issue of how levels of these molecules change when peripheral tolerance is compromised. ${ }^{118,119}$ Another study has suggested that programmed death-1, a negative regulatory molecule expressed on activated $\mathrm{CD}^{+}$and $\mathrm{CD}^{+} \mathrm{T}$ cells, maintains immune homeostasis and self-tolerance through a miRNA (miR-21) signaling cascade. ${ }^{120}$

The studies looking at epigenetic control of tolerance have probably only touched the tip of the iceberg with respect to the complexity of the levels of control and likely mechanisms; however, they do provide support that this is one way in which epigenetics could affect autoimmunity.

\section{Epigenetics and human leukocyte}

\section{antigen (HLA)-disease associations}

A large number of autoimmune diseases are strongly linked to carriage of specific HLA (particularly HLA class II) molecules; interestingly, however, HLA linkage for some autoimmune diseases varies around the globe. In MS, for example, linkage is with DRB1*1501 in Caucasian populations and DRB $1 * 0301, \mathrm{DRB} 1 * 0405$, and DRB $1 * 1303$ in Sardinia, but DRB1*07 in continental Italy and DRB1*13 in
Israel. It has been shown that coordinated changes of histone modifications and HDAC mobilization regulate the induction of HLA class II genes ${ }^{121}$ and proposed that the different HLA associations observed in MS patients across the globe are a reflection of specific environmental factors influencing epigenetic marks on liable haplotypes, which affect the expression or function of class II genes and permit the MS pathogenic cascade. ${ }^{122}$ In MS, there is also some evidence of epigenetic modification of HLA molecules contributing to the inheritance of disease susceptibility, particularly transmission from mothers to offspring. ${ }^{123,124}$

Other diseases have been less well studied, but in autoimmune diseases where HLA linkage is important, epigenetic modification of the HLA molecules could possibly modify the HLA linkage. In diseases such as ankylosing spondylitis, where there is strong HLA linkage and good concordance between MZ twins, this is less likely to play a role.

\section{Abnormal epigenetic marks on peripheral blood mononuclear cell (PBMC) subsets}

There have been multiple reports of altered levels of epigenetic marks in PBMCs and subsets of these, particularly B and T cells, from patients with autoimmune disease compared with healthy controls: these are summarized in Table 3. Some alterations appear to be relatively disease specific, whereas others may relate more to the autoimmune phenotype. PBMCs from patients with SLE have been studied extensively and recently reviewed: ${ }^{125,126}$ in brief, there is global hypomethylation of B and T cells, alterations in DNMT expression and in histone acetylation, particularly affecting genes related to apoptosis, and changes to levels of specific miRNAs. The mechanisms by which these changes in epigenetic marks modulate specific cellular processes are currently the subject of intense research interest.

\section{Epigenetic modifications in the target organ}

As noted, epigenetic changes in some autoimmune diseases are particularly notable in cells of the immune system; however, changes in the target organ could also render the organ more susceptible to autoimmune attack. Such failure of target-organ resistance could play a role in the development of autoimmune disease. ${ }^{127,128}$ What is still unknown is whether epigenetic changes in both the immune system and the target organ are required for development of autoimmune disease, whether changes in one are more likely to occur than changes in the other (eg, whether organs/cell systems that turn over more rapidly are more likely to be affected), or whether the 
Table 3 Abnormal epigenetic marks on peripheral blood leukocytes in autoimmune diseases

\begin{tabular}{|c|c|c|}
\hline Cell type & Disease & Epigenetic modification \\
\hline \multirow[t]{5}{*}{ B cells } & SLE $^{190,266-269}$ & Global DNA hypomethylation \\
\hline & & $\downarrow$ DNMTI \\
\hline & & $\downarrow \mathrm{HDACl}$ \\
\hline & & CD5 (EIB isoform) demethylation \\
\hline & & Demethylation of HERV LINE-I \\
\hline \multirow[t]{24}{*}{$\mathrm{CD}^{+} \mathrm{T}$ cells } & $\mathrm{RA}^{270}$ & $\uparrow \operatorname{miR}-146$ \\
\hline & SLE $^{271-275}$ & Global DNA hypomethylation \\
\hline & & $\downarrow$ DNMTI \\
\hline & & $\downarrow$ DNMT3a \\
\hline & & $\uparrow \mathrm{MBDI}$ \\
\hline & & $\uparrow \mathrm{MBD} 3$ \\
\hline & & $\uparrow \mathrm{MBD} 4$ \\
\hline & & $\downarrow$ HDAC2 and HDAC7 \\
\hline & & Global H3 and $\mathrm{H} 4$ hypoacetylation and hypermethylation, $\uparrow$ miR- 126 \\
\hline & & Demethylation of $C D / I A, C D 70$ and $C D / 54$ (in women) \\
\hline & Sjögren's ${ }^{276}$ & Demethylation of $C D 70$ promoter regulatory elements ${ }^{276}$ \\
\hline & Scleroderma $a^{273,277}$ & Global DNA hypomethylation \\
\hline & & CD70 promoter demethylation \\
\hline & & $\downarrow \mathrm{DNMTI}, \downarrow \mathrm{MBD} 3, \downarrow \mathrm{MBD} 4$ \\
\hline & Dermatomyositis $^{273}$ & $\uparrow \mathrm{MBD} 2$ \\
\hline & & $\uparrow \mathrm{MeCP} 2$ \\
\hline & $\mathrm{RA}^{49,278,279}$ & Global DNA hypomethylation \\
\hline & & $\uparrow \mathrm{miR}-223$ \\
\hline & & Demethylation of IFNG and FOXP3 in CD4 $4^{+} T$ cells infiltrating the joint ${ }^{280}$ \\
\hline & MS (relapsing-remitting) ${ }^{280,281}$ & $\uparrow$ miR-17-5p and miR-193a \\
\hline & & $\uparrow \mathrm{miR}-326$ (in ThI7 cells) \\
\hline & & $\downarrow$ miR-497, miR-I and miR- 126 \\
\hline & & Demethylation of FOXP3 \\
\hline & Primary biliary cirrhosis ${ }^{282}$ & Demethylation of CD40L promoter \\
\hline \multirow[t]{2}{*}{$\mathrm{CD}^{+} \mathrm{T}$ cells } & $\mathrm{SLE}^{15,283}$ & Global DNA hypomethylation \\
\hline & & Perforin promoter demethylation \\
\hline Monocytes & TID & Differential methylation of 132 different $C_{p G}$ sites \\
\hline \multirow[t]{8}{*}{ PBMCs } & $\mathrm{SLE}^{284}$ & $\downarrow$ miR-146, miR-I7-5p, miR-II2, miR-I4I, miR-184, miR-196a \\
\hline & & miR-383, miR-409-3p \\
\hline & & $\uparrow$ miR-2I, miR-6I, miR-78, miR-I42-3p, miR-189, miR-198, \\
\hline & & miR-298, miR-299pp, miR-342 \\
\hline & $\mathrm{RA}^{49}$ & $\uparrow \operatorname{miR}-146$, miR-I55, miR-132, miR-16 \\
\hline & & Global histone hyperacetylation \\
\hline & & Demethylation of $C D 2 I$ \\
\hline & TID 285 & Altered histone methylation \\
\hline
\end{tabular}

Abbreviations: DNMT, DNA methyl-transferase; HDAC, histone deacetylase; HERV LINE-I, human endogenous retroviral element long interspersed repetitive element I; MBD, methylated-DNA binding domain; MeCP2, methyl CPG binding protein 2; MS, multiple sclerosis; PBMCs, peripheral blood mononuclear cells; RA, rheumatoid arthritis; SLE, systemic lupus erythematosus; TID, type I diabetes mellitus.

type of autoimmune disease (ie, organ specific vs systemic) correlates more with epigenetic changes in the target organ than in the immune system.

During the last 2-3 years, a substantial body of evidence has accumulated to suggest that epigenetic changes in the target organ are important in some autoimmune diseases. For example, in synovial tissues from patients with RA, there is hypomethylation of DNA, ${ }^{129}$ decreases in levels of HDAC1 and HDAC2 and hyperacetylation of histones $\mathrm{H} 3$ and $\mathrm{H} 4,{ }^{130}$ and hypomethylation of histone H3 at lysine 9. Similarly, in MS patients, compared with healthy individuals, there is hypomethylation of DNA from normal-appearing central nervous system white matter, but not from tissue in the thymus, demonstrating that the target organ alone can show epigenetic changes. ${ }^{131}$ In anti-neutrophil cytoplasmic antibody vasculitis, there is upregulation of the target antigen due to perturbation of epigenetic gene-silencing mechanisms. ${ }^{132}$ SLE is a special case when considering the target organ, as the target organ of SLE, the cell nucleus, is also the site of the epigenetic effects. Multiple studies over a number of years 
have shown that modifications to both DNA and histones can affect their antigenicity. Apoptotic hypomethylated DNA and posttranslationally modified histones are known to be major targets of autoantibodies in SLE. ${ }^{133-136}$ Table 4 lists changes in epigenetic marks that are seen in the target tissue of some autoimmune diseases. In some cases, the interpretation of the target-tissue data might be made more difficult by the presence of immune cells or other inflammatory mediators within the target organ.

\section{What stimuli might induce epigenetic changes that lead to the development of autoimmunity?}

In most cases, the nature of the specific stimuli that lead to the epigenetic changes seen in patients with autoimmune disease remain undefined, but could include many diverse stimuli, both external (eg, diet, exposure to sunlight, environmental chemicals, toxins, and drugs/pharmaceuticals) and internal (eg, aging, stress, sex hormones). A complicating factor in studies of stimuli of epigenetic changes is that, while some epigenetic effects are manifested in the generation of patients that are exposed to the modifying agent, in other cases, it appears that disease occurs predominantly one or two generations after the exposure. ${ }^{137}$

It is also of interest to consider how different stimuli might differentially affect males and females, given the higher incidence of autoimmunity in females (Table 2) ${ }^{77-79}$ For epigenetic modifications to explain sexual dimorphism in autoimmunity, it is necessary to suppose that epigenetic factors are more commonly encountered in one sex than in the other, or that members of one sex are more vulnerable than the other: this is speculative. However, in view of the increase in some autoimmune diseases among women, but not men, over the last 100 years, ${ }^{138-142}$ and the major societal changes that have particularly affected women over that time, it is an attractive hypothesis.

\section{Effects of external exposure to agents that induce epigenetic changes \\ Diet and nutrition}

The diet provides the methyl donors (methionine, choline) and cofactors (folic acid, vitamin B12 and pyridoxal phosphate) essential for DNA and histone methylation. ${ }^{143}$ It is now well recognized that susceptibility to adult-onset chronic disease is influenced by persistent adaptations to prenatal and early postnatal nutrition. ${ }^{144,145}$ Furthermore, there are also reports of diet-induced epigenetic changes in the adult state. For example, dietary components such as alcohol, vitamin B6, and vitamin A have been linked to DNA methylation within the gastrointestinal tract and development of colorectal cancer ${ }^{146-149}$ and diets such as the "epigenetic diet" have been popularized as a means of controlling cancer via epigenetic modification. ${ }^{150}$

It has been proposed that epigenetic links between nutrition and autoimmunity may well contribute to the epidemiology observed for numerous autoimmune diseases ${ }^{151}$ however, while studies in animals using arbitrarily chosen dietary elements tend to support this proposal, human data from real-life clinical settings or randomized clinical trials remains inconclusive at present. There are, however,

Table 4 Changes in epigenetic marks seen in the target tissue of some autoimmune diseases

\begin{tabular}{|c|c|c|}
\hline Disease & Tissue & Epigenetic modification \\
\hline SLE & Cell nucleus & $\begin{array}{l}\text { Tri-acetylated histone } \mathrm{H} 4 \text {, ubiquitinated histone } \mathrm{H} 2 \mathrm{~A} \text {, and acetylated } \\
\text { histone } \mathrm{H} 2 \mathrm{~B} \text { are targets of autoantibodies from many patients }{ }^{135,136,286}\end{array}$ \\
\hline RA & Synovial tissue & $\begin{array}{l}\text { DNA demethylation }{ }^{129} \\
\uparrow \text { miR-I55, miR-I } 46 \text { a, miR-203 }{ }^{287,288} \\
\uparrow \text { levels of histone acetyltransferases }{ }^{130} \\
\text { Hypermethylation of death-receptor } 3 \text { (DR3) }{ }^{289} \\
\text { Demethylation of HERV LINE-I I } 290\end{array}$ \\
\hline TID & Pancreas & Insulin promoter regulated by DNA methylation \\
\hline Primary biliary cirrhosis & Liver & $\downarrow \mathrm{miR}-122 \mathrm{a}$ and miR-26a and $\uparrow \mathrm{miR}-328$ and $\mathrm{miR}-299-5 \mathrm{p}^{291}$ \\
\hline Sjögren's & Salivary glands & Altered levels of miR-I46a and miR-I $55^{292}$ \\
\hline Psoriasis & Skin & $\begin{array}{l}\text { Altered levels of miR-3I, miR-203 and miR-I } 42-3 p^{293} \\
\text { Altered DNA methylation patterns }{ }^{294} \\
\text { Demethylation of SHP-I promoter }{ }^{295}\end{array}$ \\
\hline MS & CNS white matter & $\begin{array}{l}\text { Hypomethylation of PAD2 (causes } \uparrow \text { MBP citrullination) }{ }^{131} \\
\text { Histone modification of PAD4 (causes } \uparrow \text { MBP citrullination) }{ }^{296}\end{array}$ \\
\hline Scleroderma & Fibroblasts & Aberrant methylation of FLII (causes $\uparrow$ collagen synthesis) ${ }^{297}$ \\
\hline
\end{tabular}

Abbreviations: CNS, central nervous system; HERV LINE-I, human endogenous retroviral element long interspersed repetitive element I; MBD, methylated-DNA binding domain; MS, multiple sclerosis; RA, rheumatoid arthritis; SLE, systemic lupus erythematosus; TID, type I diabetes mellitus. 
suggestions that obesity may predispose to autoimmune disease. ${ }^{152}$ In MS, for example, either maternal obesity and diabetes ${ }^{153}$ or teenage obesity ${ }^{154}$ may predispose to later MS; increased lipid levels are associated with worse outcome; ${ }^{155}$ and increased levels of the adipose-derived hormone, leptin, are associated with decreased numbers of Tregs in patients with MS. ${ }^{156}$ There is much evidence to support epigenetic regulation of numerous genes, including many immunerelated genes, as a consequence of obesity, ${ }^{157}$ although such studies are thus far lacking in obese individuals with autoimmune disease.

\section{Environmental exposures}

There is considerable evidence that prevalence rates for autoimmune diseases, including MS, T1D, RA, dermatomyositis, and polymyositis, ${ }^{158-161}$ increase as latitude increases; thus, it is thought that increased exposure to sunlight and ultraviolet radiation (UVR) in areas of lower latitude might be protective, possibly via vitamin $\mathrm{D},{ }^{162}$ although recent studies suggest that the protective effects of UVR are not necessarily dependent on vitamin D. ${ }^{163}$ UVR is known to induce multiple epigenetic changes, many of which are immunosuppressive, including hypermethylation of numerous gene promoters, phosphorylation of histone $\mathrm{H} 3$, and acetylation of histones H3 and H4. ${ }^{164,165}$ A possible explanation for reduced autoimmunity in men compared with women would be that, generally, males have more sun exposure and use less sun protection than females; ${ }^{166}$ however, while females may have less UVR exposure, there could also be biological differences between males and females in response to UVR, as there are gender differences in the degree of carcinogenesis and inflammation after ultraviolet exposure in mice. ${ }^{167}$ With respect to vitamin D, it is now known that vitamin D controls the transcription of many genes through multiple epigenetic effects via vitamin D response elements. ${ }^{168}$ In addition, there appear to be gender differences in the effects of vitamin D on gene expression; ${ }^{169}$ it has been shown, for example, that higher levels of vitamin D are associated with a lower incidence of MS only in women. ${ }^{170}$

There are many reports of "outbreaks" of autoimmunity, which tend to occur in areas where there is increased exposure to heavy metals. ${ }^{171,172}$ It has been found that nickel, cadmium, lead, aluminum, mercury, and arsenic (all of which are widespread environmental contaminants) can exert immunomodulatory and toxic effects through epigenetic mechanisms such as global changes to DNA methylation, histone modifications, and changes in levels of miRNAs. ${ }^{173,174}$
Another common environmental exposure that has been linked to increased prevalence of many autoimmune diseases is tobacco smoke. ${ }^{175}$ In addition to nicotine, smokers are exposed to over 6000 other chemicals generated by the burning tobacco, many of which are known to be antigenic, cytotoxic, mutagenic, or carcinogenic. A recent study suggests that maternal smoking can deregulate placental methylation in a CpG site-specific manner that correlates with meaningful alterations in gene expression, particularly along oxidative stress pathways. ${ }^{176}$

\section{Drugs/pharmaceuticals}

Several drugs, most notably procainamide and hydralazine, are known to cause increases in antinuclear antibodies in most people and lupus-like symptoms in some individuals. ${ }^{177}$ Both procainamide and hydralazine induce hypomethylation of DNA, but via different pathways: procainamide is a competitive inhibitor of DNMT1 ${ }^{178}$ whereas hydralazine inhibits DNMT1 upregulation during mitosis by blocking the extracellular signal-regulated kinase (ERK) signaling pathway at PKC $\delta .{ }^{179}$ Chemicals in cosmetics have also been suggested to act as a trigger for primary biliary cirrhosis, ${ }^{180}$ but the exact mechanisms by which these might act have not yet been elucidated, and thus far there are no studies regarding cosmetics and other autoimmune diseases.

Chemicals that mimic the effects of estrogen (eg, phytoestrogens or drugs such as diethylstilbestrol) are known to exert major epigenetic effects during fetal development, ${ }^{181-183}$ with the dose and timing of exposure in relation to the developmental age of the fetus markedly affecting the outcomes. Thus far, evidence linking these to autoimmune disease is equivocal, ${ }^{184}$ although studies are limited. Another possibility that has been considered is that exposure to the oral contraceptive pill might have influenced increasing female incidence of autoimmune disease over the last 30-40 years. Recent studies show that females using the oral contraceptive pill have lower global DNA methylation levels than females who do not use oral contraceptives; ${ }^{185}$ however, no specific link between the incidence of autoimmune disease and use of oral contraceptives has yet been identified. There have been reports of worsening of autoimmune disease following assisted reproduction treatment (ART), ${ }^{186}$ but so far no clear evidence that children conceived through ART have an increased risk of developing autoimmunity (although the oldest of these children are only now in their early thirties). ART generally involves the use of hormone therapy (with gonadotropin-releasing hormone agonists, folliclestimulating hormone, luteinizing hormone, human chorionic 
gonadotropin, or progesterone) to induce ovulation or to assist in implantation. Recent studies suggest that ART is associated with lower mean methylation at $\mathrm{CpG}$ sites in the placenta and higher mean methylation at $\mathrm{CpG}$ sites in cord blood, on both imprinted and non-imprinted genes; ${ }^{187,188}$ whether or not these observations will translate to increased levels of autoimmunity in children conceived in this manner remains to be seen. No studies have specifically addressed the issue of whether ART might induce detrimental epigenetic changes in mothers who already have an autoimmune disease.

\section{Retroviruses}

Human retroviruses have been linked to multiple autoimmune diseases for many years, ${ }^{189}$ although absolute proof that they cause disease is still lacking. However, a large part ( $8 \%)$ of the human genome is comprised of human endogenous retroviral elements (HERVs) that have incorporated into the primate genome over millions of years. Normally, HERVs are repressed by DNA methylation and other mechanisms; however, it has recently been reported that there is hypomethylation of the HERV long interspersed repetitive element 1 in B and T cells of SLE patients. ${ }^{190}$ This could lead to expression of retroviral proteins in the lymphocytes, with potential consequences for the integrity, physiology, and immune function of these cells and subsequent development of autoimmunity.

\section{"Internal" factors that could lead to epigenetic changes of relevance to autoimmunity Aging}

Aging is associated with changes in patterns of gene expression; whether these changes are due primarily to epigenetic alterations or genetic alterations (ie, accumulated DNA damage) is not clear, but it is feasible that epigenetics accounts for at least part of the change. Early studies in mammals found age-associated increases in methylation of CpG islands ${ }^{191}$ and of histone H4K20; ${ }^{192}$ both of these epigenetic marks correlate with transcriptional repression. More recent studies of twins have shown that, although MZ twins are epigenetically indistinguishable during the early years of life, older MZ twins exhibit many differences in their overall content and genomic distribution of methylated DNA and histone acetylation and their gene-expression portrait. ${ }^{193,194}$ In a genome-scale study of epigenomic dynamics during normal human aging, Rakyan et $\mathrm{al}^{195}$ identified aging-associated differentially methylated regions, which became hypermethylated with aging, predominantly at bivalent chromatin domain promoters. Bivalent chromatin domains, which contain two methylation sites with conflicting output (H3K4 and H327 - see Table 1) are characteristic of pluripotent cells, but methylation of one site dominates as the cells differentiate. ${ }^{196}$ This is of interest, as Polycomb-group proteins catalyze the methylation of $\mathrm{H} 3 \mathrm{~K} 27$, and it has also been reported that Polycomb-group protein target genes are far more likely to become methylated with age than nontargets. ${ }^{197}$ Since most autoimmune diseases do not develop until the third or fourth decade of life (with notable exceptions such as T1D), accumulation of epigenetic changes with aging may provide the impetus for the onset of disease in susceptible individuals.

\section{Stress}

Physical and psychological stresses have been suggested as being potential modulators in the development of autoimmune disease. ${ }^{198}$ Hypomethylation of promoter regions of genes encoding glucocorticoid receptors and brain-derived neurotrophic factor have been reported fairly frequently in offspring whose mothers experienced stressful events during pregnancy. Adolescents whose parents experienced adversity during the adolescent's infancy or preschool years also showed differences in the numbers of methylated $\mathrm{CpG}$ sites compared with controls, although these differences were not found to be associated with specific genes. ${ }^{199}$ Interestingly, maternal stressors in infancy, but paternal stressors in the preschool years, are most strongly predictive of differential methylation and the patterning of such epigenetic marks varies by the child's gender, with girls showing higher levels of differentially methylated CpG sites than boys. ${ }^{199}$

Quality of early maternal care has also long been acknowledged to have long-term repercussions during the lifetime of an individual. Studies in rats have shown that, in the absence of appropriate maternal nurturing, there is less methylation of the gene encoding the glucocorticoid receptor in the hippocampus, resulting in overexpression of the receptor in later life. ${ }^{200}$ The implication is that the glucocorticoidmediated stress-response pathway is epigenetically fixed at the level of gene transcription.

\section{Effects of exposure to estrogen}

As noted earlier, chemicals that can mimic the effects of estrogen can exert major epigenetic effects during fetal development; similarly, levels of naturally occurring estrogens in the mother during pregnancy can also epigenetically influence fetal development, particularly in the developing brain. ${ }^{201}$ Almost all of the papers looking at the epigenetic modifying effects of estrogens consider them in terms of effects on the 
fetus; surprisingly little work has been reported regarding the epigenetic effects on the mother of the greatly elevated levels of estrogens during pregnancy. ${ }^{202}$ However, the state of being pregnant has short- and long-term beneficial effects on some females with autoimmune disease. In MS, for example, there are reports of favorable long-term effects of childbirth on the course of MS, particularly if the child was born after the onset of MS, ${ }^{203-205}$ and women who have never had children are reported to take a shorter time to reach a higher level of disability than are women who have had children at any time. ${ }^{203}$ While these studies could simply indicate that women with more aggressive disease are just less inclined to have children, another possibility is that pregnancy induces long-term protective epigenetic effects in the mother. To understand how/ if epigenetic effects of estrogen or other pregnancy-related hormones might help to improve autoimmunity, it will first be necessary to determine the epigenetic marks associated with these hormones in normal healthy cells and organs and compare these with the same patterns in diseased or dysfunctional ones. This information is still lacking.

\section{Exercise}

Exercise has numerous health benefits and has effects on the immune system, where it has been shown that exercise in low levels is anti-inflammatory. ${ }^{206}$ Anecdotal evidence suggests a beneficial role of exercise in autoimmunity, although data from controlled trials is scarce. ${ }^{207}$ It has been reported that exercise can alter gene expression in skeletal muscle through epigenetic mechanisms, including gene-specific DNA hypomethylation, ${ }^{208}$ and increased acetylation of $\mathrm{H} 3 \mathrm{~K} 36$, a site associated with transcriptional elongation, combined with export from the nucleus of HDAC4 and HDAC5 (thereby removing their transcriptional repressive function). ${ }^{209}$ Although these observations are from small numbers of individuals, and some of the effects reported are relatively small, they suggest that at least some of the effects of exercise may come about via epigenetic modifications. If this were confirmed, it would be plausible that many of the effects of exercise in other tissues, including the immune system, also occur through epigenetic modifications.

\section{Epigenetic modification to the $\mathrm{X}$ chromosome}

$\mathrm{X}$-linked genes are typically unmethylated (active) in men, while women have one methylated (Xi) and one unmethylated (Xa) gene. It has been found that some genes on $\mathrm{Xi}$ are demethylated in females with autoimmune disease; this has been studied most thoroughly in SLE. ${ }^{210}$ The consequence of this appears to be that females can have elevated levels of expression of molecules encoded on the X chromosome, due to gene dosage irregularities. In support of this, it has been shown that treatment of CD4 ${ }^{+}$ T cells with the DNMT inhibitor 5-azacytidine leads to elevated levels of CD40 ligand (CD154 - which is encoded on the X chromosome) on $\mathrm{T}$ cells from females but not males. ${ }^{211}$ There are observations of elevated levels of CD154 in a multitude of autoimmune disorders, including SLE, autoimmune thyroid disease, T1D, inflammatory bowel disease, psoriasis, MS, and RA. Although the gender of patients has not always been specified in these studies, the results suggest that demethylation of genes on the Xi may be a fairly common epigenetic mechanism in autoimmune disease. Several molecules thought to be of great potential importance for autoimmunity are encoded on the $\mathrm{X}$ chromosome; these include: the interleukin (IL) $2 \mathrm{R} \gamma$ chain (also known as the "common $\gamma$ chain" because it is shared by receptors for IL2, IL7, IL15, and IL21); ${ }^{212}$ Foxp3, the master regulator in the development and function of Tregs; ${ }^{213}$ tissue inhibitors of metalloproteinases $1-4$, which are important in inflammation; ${ }^{214}$ the X-linked inhibitor of apoptosis that regulates $\mathrm{T}$ cell function; ${ }^{215}$ and toll-like receptor 7 and toll-like receptor 8 , which are pattern-recognition receptors, both of which are important in recognition of single-stranded RNA. ${ }^{216}$ There are also a large number of $\mathrm{X}$-linked genes encoding possible target antigens of autoimmune disease: changes in dosage of these autoantigens could also provide an initiating event for development of autoimmunity. This is an area of research that is just opening up and it is likely that the next few years will dramatically increase our understanding of how $\mathrm{X}$ chromosome regulation might be involved in the development of autoimmunity.

Skewing of $\mathrm{X}$ inactivation, so that there is an overrepresentation of the Xa from one parent, has been reported in females with some autoimmune diseases, including autoimmune thyroid disease and scleroderma, ${ }^{217-220}$ but not in SLE or MS. ${ }^{221,222}$ As noted earlier, the process of $\mathrm{X}$ inactivation has multiple layers of epigenetic controls; thus, the potential for modulation of this process is high. Skewed X inactivation could influence expression of genes on the $\mathrm{X}$ chromosome and could lead to inactivation of a gene that protects against autoimmunity, or overexpression of a susceptibility gene, leading to increased autoimmune disease.

\section{The next steps}

Experimental evidence of a major role for epigenetically modified gene expression in the development of autoimmunity is accumulating at an ever-increasing pace, but there are many aspects still not understood. Over the last couple of years, the 


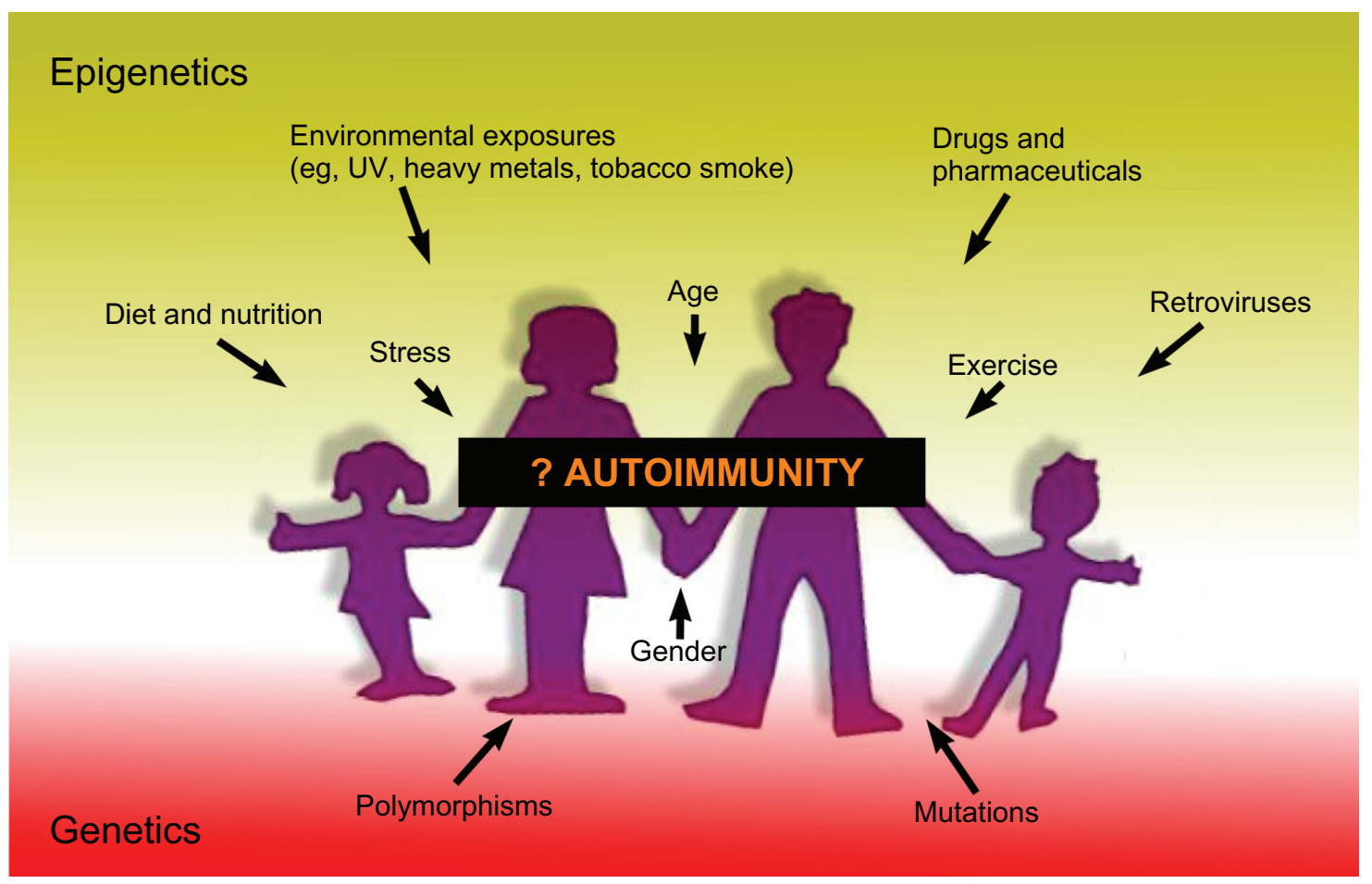

Figure 3 Summary of factors that may lead to the development of autoimmunity.

Notes: Underlying genetic factors, such as polymorphisms or mutations in certain genes, may be necessary to predispose to autoimmunity. Epigenetic factors, both from external sources (eg, environmental exposures, diet and nutrition, drugs and pharmaceuticals, retroviruses) and internal (eg, aging, gender, and stress and exercise levels), acting on the immune system and/or the target organ, may all contribute to either enhancing the development of autoimmunity or protecting against it. ? indicates that we are still unsure which of these factors might lead to autoimmunity.

Abbreviation: UV, ultraviolet.

global methylation measures, which have been used in many of the studies noted in this review, have been superseded by new technologies involving next-generation sequencing that can dramatically increase the amount and detail of the information that can be obtained regarding epigenetic modifications. ${ }^{223-226}$ Integrating the extensive genome-wide association study data that are available from many autoimmune diseases with methylome, chromatin epigenomic, and ncRNA data would be one way to potentially maximize our understanding of how the interaction of genetic and epigenetic factors increases susceptibility to or protection against autoimmune disease (Figure 3). Although, as has been pointed out, ${ }^{227}$ because epigenetic marks are known to change over the lifetime of an individual, it is harder to study with the same certainty as genetic association the association of epigenetics with disease.

However, improving our understanding of the role that epigenetic modifications play in the development of autoimmunity is likely to increase the prospects for controlling or preventing autoimmune disease through the use of drugs that target proteins controlling chromatin modifications (eg, HDAC inhibitors), DNA methylation (eg, inhibitors of DNA methyltransferases), or other epigenetic mechanisms.

\section{Disclosure}

The authors declare no conflicts of interest in this work.

\section{References}

1. Li B, Carey M, Workman JL. The role of chromatin during transcription. Cell. 2007;128(4):707-719.

2. Margueron R, Reinberg D. Chromatin structure and the inheritance of epigenetic information. Nat Rev Genet. 2010;11(4):285-296.

3. Waddington CH. The epigenotype. Int J Epidemiol. 2012;41(1): 10-13.

4. Nanney DL. Epigenetic control systems. Proc Natl Acad Sci U S A. 1958;44(7):712-717.

5. Holliday R. The inheritance of epigenetic defects. Science. 1987; 238(4824):163-170.

6. Jeppesen P. Histone acetylation: a possible mechanism for the inheritance of cell memory at mitosis. Bioessays. 1997;19(1):67-74.

7. Turner BM. Histone acetylation and an epigenetic code. Bioessays. 2000;22(9):836-845.

8. Grewal SI, Moazed D. Heterochromatin and epigenetic control of gene expression. Science. 2003;301(5634):798-802.

9. Ptashne M. On the use of the word 'epigenetic'. Curr Biol. 2007;17(7): R233-R236.

10. Ooi SK, Qiu C, Bernstein E, et al. DNMT3L connects unmethylated lysine 4 of histone $\mathrm{H} 3$ to de novo methylation of DNA. Nature. 2007;448(7154):714-717.

11. Zhang Y, Reinberg D. Transcription regulation by histone methylation: interplay between different covalent modifications of the core histone tails. Gene Dev. 2001;15(18):2343-2360.

12. Klose RJ, Bird AP. Genomic DNA methylation: the mark and its mediators. Trends Biochem Sci. 2006;31(2):89-97.

13. Bird A. Perceptions of epigenetics. Nature. 2007;447(7143):396-398. 
14. Haig D. Commentary: The epidemiology of epigenetics. Int J Epidemiol. 2012;41(1):13-16.

15. Hewagama A, Richardson B. The genetics and epigenetics of autoimmune diseases. J Autoimmun. 2009;33(1):3-11.

16. Meda F, Folci M, Baccarelli A, Selmi C. The epigenetics of autoimmunity. Cell Mol Immunol. 2011;8(3):226-236.

17. Ehrlich M, Gama-Sosa MA, Huang LH, et al. Amount and distribution of 5-methylcytosine in human DNA from different types of tissues of cells. Nucleic Acids Res. 1982;10(8):2709-2721.

18. Takai D, Jones PA. Comprehensive analysis of $\mathrm{CpG}$ islands in human chromosomes 21 and 22. Proc Natl Acad Sci U SA. 2002;99(6):3740-3745.

19. Illingworth RS, Bird AP. CpG islands - 'a rough guide'. FEBS Lett. 2009;583(11):1713-1720.

20. Mariño-Ramírez L, Spouge JL, Kanga GC, Landsman D. Statistical analysis of over-represented words in human promoter sequences. Nucleic Acids Res. 2004;32(3):949-958.

21. Jones PA. Functions of DNA methylation: islands, start sites, gene bodies and beyond. Nat Rev Genet. 2012;13(7):484-492.

22. Illingworth R, Kerr A, DeSousa D, et al. A novel CpG island set identifies tissue-specific methylation at developmental gene loci. PLoS Biol. 2008;6(1):e22.

23. Maunakea AK, Nagarajan RP, Bilenky M, et al. Conserved role of intragenic DNA methylation in regulating alternative promoters. Nature. 2010;466(7303):253-257.

24. Panning B, Jaenisch R. DNA hypomethylation can activate Xist expression and silence X-linked genes. Gene Dev. 1996;10(16): 1991-2002.

25. Sleutels F, Zwart R, Barlow DP. The non-coding Air RNA is required for silencing autosomal imprinted genes. Nature. 2002; 415(6873):810-813.

26. Irizarry RA, Ladd-Acosta C, Wen B, et al. The human colon cancer methylome shows similar hypo- and hypermethylation at conserved tissue-specific CpG island shores. Nat Genet. 2009;41(2):178-186.

27. Stadler MB, Murr R, Burger L, et al. DNA-binding factors shape the mouse methylome at distal regulatory regions. Nature. 2011;480(7378):490-495.

28. Wiench M, John S, Baek S, et al. DNA methylation status predicts cell type-specific enhancer activity. EMBO J. 2011;30(15):3028-3039.

29. Kriaucionis S, Heintz N. The nuclear DNA base 5-Hydroxymethylcytosine is present in Purkinje neurons and the brain. Science. 2009;324(5929):929-930.

30. Williams K, Christensen J, Helin K. DNA methylation: TET proteins - guardians of CpG islands? EMBO Rep. 2012;13(1):28-35.

31. Pastor WA, Pape UJ, Huang Y, et al. Genome-wide mapping of 5-hydroxymethylcytosine in embryonic stem cells. Nature. 2011; 473(7347):394-397.

32. Stroud H, Feng S, Morey Kinney S, Pradhan S, Jacobsen SE. 5-Hydroxymethylcytosine is associated with enhancers and gene bodies in human embryonic stem cells. Genome Biol. 2011;12(6):R54.

33. Jones PA, Liang G. Rethinking how DNA methylation patterns are maintained. Nat Rev Genet. 2009;10(11):805-811.

34. Ballestar E. An introduction to epigenetics. Adv Exp Med Biol. 2011;711:1-11.

35. Métivier R, Gallais R, Tiffoche C, et al. Cyclical DNA methylation of a transcriptionally active promoter. Nature. 2008;452(7183):45-50.

36. Ooi SK, Bestor TH. The colorful history of active DNA demethylation. Cell. 2008;133(7):1145-1148.

37. Booth MJ, Branco MR, Ficz G, et al. Quantitative sequencing of 5-methylcytosine and 5-hydroxymethylcytosine at single-base resolution. Science. 2012;336(6083):934-937.

38. Eden S, Cedar H. Role of DNA methylation in the regulation of transcription. Curr Opin Genet Dev. 1994;4(2):255-259.

39. Curradi M, Izzo A, Badaracco G, Landsberger N. Molecular mechanisms of gene silencing mediated by DNA methylation. Mol Cell Biol. 2002;22(9):3157-3173.

40. Hendrich B, Bird A. Identification and characterization of a family of mammalian methyl-CpG binding proteins. Mol Cell Biol. 1998; 18(11):6538-6547.
41. Smith CL, Peterson CL. A conserved Swi2/Snf2 ATPase motif couples ATP hydrolysis to chromatin remodeling. Mol Cell Biol. 2005;25(14):5880-5892.

42. Fischle W, Tseng BS, Dormann HL, et al. Regulation of HP1-chromatin binding by histone $\mathrm{H} 3$ methylation and phosphorylation. Nature. 2005;438(7071):1116-1122.

43. Shogren-Knaak M, Ishii H, Sun JM, Pazin MJ, Davie JR, Peterson CL. Histone H4-K16 acetylation controls chromatin structure and protein interactions. Science. 2006;311(5762):844-847.

44. Gregory PD, Wagner K, Hörz W. Histone acetylation and chromatin remodeling. Exp Cell Res. 2001;265(2):195-202.

45. Neumann H, Hancock SM, Buning R, et al. A method for genetically installing site-specific acetylation in recombinant histones defines the effects of H3 K56 acetylation. Mol Cell. 2009;36(1):153-163.

46. Li G, Margueron R, Hu G, Stokes D, Wang YH, Reinberg D. Highly compacted chromatin formed in vitro reflects the dynamics of transcription activation in vivo. Mol Cell. 2010;38(1):41-53.

47. Chen P, Li G. Dynamics of the higher-order structure of chromatin. Protein Cell. 2010;1(11):967-971.

48. Scharf AN, Imhof A. Every methyl counts - epigenetic calculus. FEBS Lett. 2011;585(13):2001-2007.

49. Ballestar E. Epigenetic alterations in autoimmune rheumatic diseases. Nat Rev Rheumatol. 2011;7(5):263-271.

50. Kouzarides T. Chromatin modifications and their function. Cell. 2007;128(4):693-705.

51. Sanchez R, Zhou MM. The PHD finger: a versatile epigenome reader. Trends Biochem Sci. 2011;36(7):364-372.

52. Clapier CR, Cairns BR. The biology of chromatin remodeling complexes. Ann Rev Biochem. 2009;78:273-304.

53. Minard ME, Jain AK, Barton MC. Analysis of epigenetic alterations to chromatin during development. Genesis. 2009;47(8):559-572.

54. Mizuguchi G, Shen X, Landry J, Wu WH, Sen S, Wu C. ATP-driven exchange of histone $\mathrm{H} 2 \mathrm{AZ}$ variant catalyzed by SWR1 chromatin remodeling complex. Science. 2004;303(5656):343-348.

55. Mattick JS. Challenging the dogma: the hidden layer of non-protein-coding RNAs in complex organisms. Bioessays. 2003;25(10):930-939.

56. Esteller M. Non-coding RNAs in human disease. Nat Rev Genet. 2011;12(12):861-874.

57. He L, Hannon GJ. MicroRNAs: small RNAs with a big role in gene regulation. Nat Rev Genet. 2004;5(7):522-531.

58. Friedman RC, Farh KK, Burge CB, Bartel DP. Most mammalian mRNAs are conserved targets of microRNAs. Genome Res. 2009;19(1):92-105.

59. Bentwich I, Avniel A, Karov Y, et al. Identification of hundreds of conserved and nonconserved human microRNAs. Nat Genet. 2005;37(7):766-770.

60. Yekta S, Shih I, Bartel DP. MicroRNA-directed cleavage of HOXB8 mRNA. Science. 2004;304(5670):594-596.

61. Mendell JT. MicroRNAs: critical regulators of development, cellular physiology and malignancy. Cell Cycle. 2005;4(9):1179-1184.

62. Roccaro AM, Sacco A, Jia X, et al. microRNA-dependent modulation of histone acetylation in Waldenström macroglobulinemia. Blood. 2010;116(9):1506-1514.

63. Sampath D, Liu C, Vasan K, et al. Histone deacetylases mediate the silencing of miR-15a, miR-16, and miR-29b in chronic lymphocytic leukemia. Blood. 2012;119(5):1162-1172.

64. Mercer TR, Dinger ME, Mattick JS. Long non-coding RNAs: insights into functions. Nat Rev Genet. 2009;10(3):155-159.

65. Gupta RA, Shah N, Wang KC, et al. Long non-coding RNA HOTAIR reprograms chromatin state to promote cancer metastasis. Nature. 2010;464(7291):1071-1076.

66. Wang X, Arai S, Song X, et al. Induced ncRNAs allosterically modify RNA-binding proteins in cis to inhibit transcription. Nature. 2008;454(7200):126-130.

67. Martianov I, Ramadass A, Serra Barros A, Chow N, Akoulitchev A. Repression of the human dihydrofolate reductase gene by a non-coding interfering transcript. Nature. 2007;445(7128):666-670. 
68. He Y, Vogelstein B, Velculescu VE, Papadopoulos N, Kinzler KW. The antisense transcriptomes of human cells. Science. 2008; 322(5909):1855-1857.

69. Lyon MF. Gene action in the X-chromosome of the mouse (Mus musculus L.). Nature. 1961;190:372-373.

70. Takagi N, Sasaki M. Preferential inactivation of the paternally derived $\mathrm{X}$ chromosome in the extraembryonic membranes of the mouse. Nature. 1975;256(5519):640-642.

71. Rastan S. Timing of X-chromosome inactivation in postimplantation mouse embryos. J Embryol Exp Morphol. 1982;71:11-24.

72. Penny GD, Kay GF, Sheardown SA, Rastan S, Brockdorff N. Requirement for Xist in X chromosome inactivation. Nature. 1996; 379(6561):131-137.

73. Herzing LB, Romer JT, Horn JM, Ashworth A. Xist has properties of the X-chromosome inactivation centre. Nature. 1997;386(6622): $272-275$.

74. Okamoto I, Otte AP, Allis CD, Reinberg D, Heard E. Epigenetic dynamics of imprinted $\mathrm{X}$ inactivation during early mouse development. Science. 2004;303(5658):644-649.

75. Cheng MK, Disteche CM. Silence of the fathers: early X inactivation. Bioessays. 2004;26(8):821-824.

76. Lucchesi JC, Kelly WG, Panning B. Chromatin remodeling in dosage compensation. Ann Rev Genet. 2005;39:615-651.

77. Zandman-Goddard G, Peeva E, ShoenfeldY. Gender and autoimmunity. Autoimmun Rev. 2007;6(6):366-372.

78. McCombe PA, Greer JM, Mackay IR. Sexual dimorphism in autoimmune disease. Curr Mol Med. 2009;9(9):1058-1079.

79. Greer JM, McCombe PA. Role of gender in multiple sclerosis: clinical effects and potential molecular mechanisms. J Neuroimmunol. 2011;234(1-2):7-18.

80. Islam T, Gauderman WJ, Cozen W, Hamilton AS, Burnett ME, Mack TM. Differential twin concordance for multiple sclerosis by latitude of birthplace. Ann Neurol. 2006;60(1):56-64.

81. Ristori G, Cannoni S, Stazi MA, et al. Multiple sclerosis in twins from continental Italy and Sardinia: a nationwide study. Ann Neurol. 2006;59(1):27-34.

82. Redondo MJ, Jeffrey J, Fain PR, Eisenbarth GS, Orban T. Concordance for islet autoimmunity among monozygotic twins. $N$ Engl J Med. 2008;359(26):2849-2850.

83. Jacobs KB, Yeager M, Zhou W, et al. Detectable clonal mosaicism and its relationship to aging and cancer. Nat Genet. 2012;44(6): $651-658$.

84. Laurie CC, Laurie CA, Rice K, et al. Detectable clonal mosaicism from birth to old age and its relationship to cancer. Nat Genet. 2012;44(6): 642-650.

85. Javierre BM, Fernandez AF, Richter J, et al. Changes in the pattern of DNA methylation associate with twin discordance in systemic lupus erythematosus. Genome Res. 2010;20(2):170-179.

86. Baranzini SE, Mudge J, van Velkinburgh JC, et al. Genome, epigenome and RNA sequences of monozygotic twins discordant for multiple sclerosis. Nature. 2010;464(7293):1351-1356.

87. Bell CG, Teschendorff AE, Rakyan VK, Maxwell AP, Beck S, Savage DA. Genome-wide DNA methylation analysis for diabetic nephropathy in type 1 diabetes mellitus. BMC Med Genomics. 2010;3:33.

88. Breitling LP, Yang R, Korn B, Burwinkel B, Brenner H. Tobaccosmoking-related differential DNA methylation: $27 \mathrm{~K}$ discovery and replication. Am J Hum Genet. 2011;88(4):450-457.

89. Rakyan VK, Down TA, Balding DJ, Beck S. Epigenome-wide association studies for common human diseases. Nat Rev Genet. 2011;12(8):529-541.

90. Gervin K, Vigeland MD, Mattingsdal M, et al. DNA methylation and gene expression changes in monozygotic twins discordant for psoriasis: identification of epigenetically dysregulated genes. PLoS Genet. 2012;8(1):e1002454.

91. Rakyan VK, Beyan H, Down TA, et al. Identification of type 1 diabetesassociated DNA methylation variable positions that precede disease diagnosis. PLoS Genet. 2011;7(9):e1002300.
92. Heijmans BT, Mill J. Commentary: The seven plagues of epigenetic epidemiology. Int J Epidemiol. 2012;41(1):74-78.

93. Wilson CB, Rowell E, Sekimata M. Epigenetic control of T-helper-cell differentiation. Nat Rev Immunol. 2009;9(2):91-105.

94. Aune TM, Collins PL, Chang S. Epigenetics and T helper 1 differentiation. Immunology. 2009;126(3):299-305.

95. Bergman Y, Cedar H. Epigenetic control of recombination in the immune system. Semin Immunol. 2010;22(6):323-329.

96. Cedar H, Bergman Y. Epigenetics of haematopoietic cell development. Nat Rev Immunol. 2011;11(7):478-488.

97. Fernández-Morera JL, Calvanese V, Rodríguez-Rodero S, Menéndez-Torre E, Fraga MF. Epigenetic regulation of the immune system in health and disease. Tissue Antigens. 2010;76(6):431-439.

98. Janson PC, Winerdal ME, Winqvist O. At the crossroads of T helper lineage commitment-Epigenetics points the way. Biochim Biophys Acta. 2009;1790(9):906-919.

99. Lal G, Bromberg JS. Epigenetic mechanisms of regulation of Foxp3 expression. Blood. 2009;114(18):3727-3735.

100. Lee GR, Kim ST, Spilianakis CG, Fields PE, Flavell RA. T helper cell differentiation: regulation by cis elements and epigenetics. Immunity. 2006;24(4):369-379.

101. Pang KC, Dinger ME, Mercer TR, et al. Genome-wide identification of long noncoding RNAs in CD8+ T cells. J Immunol. 2009;182(12): 7738-7748.

102. Sawalha AH. Epigenetics and T-cell immunity. Autoimmunity. 2008; 41(4):245-252.

103. Vanden Berghe W, Ndlovu MN, Hoya-Arias R, Dijsselbloem N, Gerlo S, Haegeman G. Keeping up NF-kappaB appearances: epigenetic control of immunity or inflammation-triggered epigenetics. Biochem Pharmacol. 2006;72(9):1114-1131.

104. Wilson CB, Makar KW, Shnyreva M, Fitzpatrick DR. DNA methylation and the expanding epigenetics of $\mathrm{T}$ cell lineage commitment. Semin Immunol. 2005;17(2):105-119.

105. Allan RS, Zueva E, Cammas F, et al. An epigenetic silencing pathway controlling T helper 2 cell lineage commitment. Nature. 2012. Epub July 4.

106. Blüml S, Zupkovitz G, Kirchberger S, et al. Epigenetic regulation of dendritic cell differentiation and function by oxidized phospholipids. Blood. 2009;114(27):5481-5489.

107. Subrahmanyam R, Sen R. Epigenetic features that regulate $\operatorname{IgH}$ locus recombination and expression. Curr Top Microbiol Immunol. 2012;356:39-63.

108. Koh AS, Kingston RE, Benoist C, Mathis D. Global relevance of Aire binding to hypomethylated lysine-4 of histone-3. Proc Natl Acad Sci US A. 2010;107(29):13016-13021.

109. Williams GT, Mourtada-Maarabouni M, Farzaneh F. A critical role for non-coding RNA GAS5 in growth arrest and rapamycin inhibition in human T-lymphocytes. Biochem Soc Trans. 2011;39(2):482-486.

110. Kino T, Hurt DE, Ichijo T, Nader N, Chrousos GP. Noncoding RNA gas5 is a growth arrest- and starvation-associated repressor of the glucocorticoid receptor. Sci Signal. 2010;3(107):ra8.

111. Ashwell JD, Lu FW, Vacchio MS. Glucocorticoids in T cell development and function. Annu Rev Immunol. 2000;18:309-345.

112. Li QJ, Chau J, Ebert PJ, et al. miR-181a is an intrinsic modulator of T cell sensitivity and selection. Cell. 2007;129(1):147-161.

113. Belkaya S, Silge RL, Hoover AR, et al. Dynamic modulation of thymic microRNAs in response to stress. PloS One. 2011;6(11):e27580.

114. Li B, Samanta A, Song X, et al. FOXP3 interactions with histone acetyltransferase and class II histone deacetylases are required for repression. Proc Natl Acad Sci U S A. 2007;104(11): 4571-4576.

115. Tao R, de Zoeten EF, Özkaynak E, et al. Deacetylase inhibition promotes the generation and function of regulatory T cells. Nat Med. 2007;13(11):1299-1307.

116. Bettini ML, Pan F, Bettini M, et al. Loss of epigenetic modification driven by the Foxp3 transcription factor leads to regulatory $\mathrm{T}$ cell insufficiency. Immunity. 2012;36(5):717-730. 
117. Beyer M, Thabet Y, Müller RU, et al. Repression of the genome organizer SATB1 in regulatory $\mathrm{T}$ cells is required for suppressive function and inhibition of effector differentiation. Nat Immunol. 2011;12(9):898-907.

118. Zhou L, Park JJ, Zheng Q, Dong Z, Mi Q. MicroRNAs are key regulators controlling iNKT and regulatory T-cell development and function. Cell Mol Immunol. 2011;8(5):380-387.

119. Song W, Tai YT, Tian Z, et al. HDAC inhibition by LBH589 affects the phenotype and function of human myeloid dendritic cells. Leukemia 2011;25(1):161-168.

120. Iliopoulos D, Kavousanaki M, Ioannou M, Boumpas D, Verginis P. The negative costimulatory molecule PD-1 modulates the balance between immunity and tolerance via miR-21. Eur J Immunol. 2011;41(6):1754-1763.

121. Gialitakis M, Kretsovali A, Spilianakis C, et al. Coordinated changes of histone modifications and HDAC mobilization regulate the induction of MHC class II genes by Trichostatin A. Nucleic Acids Res. 2006;34(3):765-772.

122. Ramagopalan SV, Ebers GC. Multiple sclerosis: major histocompatibility complexity and antigen presentation. Genome Med 2009;1(11):105.

123. Chao MJ, Ramagopalan SV, Herrera BM, et al. Epigenetics in multiple sclerosis susceptibility: difference in transgenerational risk localizes to the major histocompatibility complex. Hum Mol Genet. 2009;18(2):261-266

124. Chao MJ, Ramagopalan SV, Herrera BM, et al. MHC transmission: insights into gender bias in MS susceptibility. Neurology. 2011;76(3): 242-246.

125. Hedrich CM, Tsokos GC. Epigenetic mechanisms in systemic lupus erythematosus and other autoimmune diseases. Trends Mol Med 2011;17(12):714-724.

126. Renaudineau Y, Garaud S, Le Dantec C, Alonso-Ramirez R, Daridon C, Youinou P. Autoreactive B cells and epigenetics. Clin Rev Allergy Immunol. 2010;39(1):85-94.

127. Liston A. Autoimmunity: beyond the immune system. Immunol Cell Biol. 2008;86(4):295-296.

128. Lonyai A, Kodama S, Burger D, Faustman DL. Fetal Hox11 expression patterns predict defective target organs: a novel link between developmental biology and autoimmunity. Immunol Cell Biol. 2008;86(4):301-309.

129. Karouzakis E, Gay RE, Michel BA, Gay S, Neidhart M. DNA hypomethylation in rheumatoid arthritis synovial fibroblasts. Arthritis Rheum. 2009;60(12):3613-3622.

130. Huber LC, Brock M, Hemmatazad H, et al. Histone deacetylase/acetylase activity in total synovial tissue derived from rheumatoid arthritis and osteoarthritis patients. Arthritis Rheum. 2007;56(4):1087-1093.

131. Mastronardi FG, Noor A, Wood DD, Paton T, Moscarello MA. Peptidyl argininedeiminase $2 \mathrm{CpG}$ island in multiple sclerosis white matter is hypomethylated. J Neurosci Res. 2007;85(9):2006-2016.

132. Ciavatta DJ, Yang J, Preston GA, et al. Epigenetic basis for aberrant upregulation of autoantigen genes in humans with ANCA vasculitis. J Clin Invest. 2010;120(9):3209-3219.

133. Wen $\mathrm{ZK}, \mathrm{Xu} \mathrm{W}, \mathrm{Xu} \mathrm{L}$, et al. DNA hypomethylation is crucial for apoptotic DNA to induce systemic lupus erythematosus-like autoimmune disease in SLE-non-susceptible mice. Rheumatology 2007;46(12):1796-1803.

134. Dieker J, Muller S. Epigenetic Histone Code and Autoimmunity. Clin Rev Allergy Immunol. 2010;39(1):78-84.

135. Plaué S, Muller S, van Regenmortel MH. A branched, synthetic octapeptide of ubiquitinated histone $\mathrm{H} 2 \mathrm{~A}$ as target of autoantibodies. $J$ Exp Med. 1989;169(5):1607-1617.

136. Dieker JW, Fransen JH, van Bavel CC, et al. Apoptosis-induced acetylation of histones is pathogenic in systemic lupus erythematosus. Arthritis Rheum. 2007;56(6):1921-1933.

137. Klip H, Verloop J, van Gool JD, Koster ME, Burger CW, van Leeuwen FE; OMEGA Project Group. Hypospadias in sons of women exposed to diethylstilbestrol in utero: a cohort study. Lancet. 2002;359(9312):1102-1107.
138. Alonso A, Hernán MA. Temporal trends in the incidence of multiple sclerosis: a systematic review. Neurology. 2008;71(2):129-135.

139. Hirst M, Marra MA. Epigenetics and human disease. Int J Biochem Cell Biol. 2009;41(1):136-146.

140. Orton SM, Herrera BM, Yee IM, et al; Canadian Collaborative Study Group. Sex ratio of multiple sclerosis in Canada: a longitudinal study. Lancet Neurol. 2006;5(11):932-936.

141. Osoegawa M, Kira J, Fukazawa T, et al; Research Committee of Neuroimmunological Diseases. Temporal changes and geographical differences in multiple sclerosis phenotypes in Japanese: nationwide survey results over 30 years. Mult Scler. 2009;15(2): 159-173.

142. Furszyfer J, Kurland LT, McConahey WM, Woolner LB, Elveback LR. Epidemiologic aspects of Hashimoto's thyroiditis and Graves' disease in Rochester, Minnesota (1935-1967), with special reference to temporal trends. Metabolism. 1972;21(3):197-204.

143. Poirier LA. The effects of diet, genetics and chemicals on toxicity and aberrant DNA methylation: an introduction. J Nutr. 2002; 132(Suppl 8):2336S-2339S.

144. McGowan PO, Meaney MJ, Szyf M. Diet and the epigenetic (re) programming of phenotypic differences in behavior. Brain Res. 2008;1237:12-24.

145. Heijmans BT, Tobi EW, Stein AD, et al. Persistent epigenetic differences associated with prenatal exposure to famine in humans. Proc Natl Acad Sci U S A. 2008;105(44):17046-17049.

146. van Engeland M, Weijenberg MP, Roemen GM, et al. Effects of dietary folate and alcohol intake on promoter methylation in sporadic colorectal cancer: the Netherlands cohort study on diet and cancer. Cancer Res. 2003;63(12):3133-3137.

147. de Vogel S, Bongaerts BW, Wouters KA, et al. Associations of dietary methyl donor intake with MLH1 promoter hypermethylation and related molecular phenotypes in sporadic colorectal cancer. Carcinogenesis. 2008;29(9):1765-1773.

148. Kune G, Watson L. Colorectal cancer protective effects and the dietary micronutrients folate, methionine, vitamins B6, B12, C, E, selenium, and lycopene. Nutr Cancer. 2006;56(1):11-21.

149. Mas S, Lafuente MJ, Crescenti A, et al. Lower specific micronutrient intake in colorectal cancer patients with tumors presenting promoter hypermethylation in p16(INK4a), p4(ARF) and hMLH1. Anticancer Res. 2007;27(2):1151-1156.

150. Hardy TM, Tollefsbol TO. Epigenetic diet: impact on the epigenome and cancer. Epigenomics. 2011;3(4):503-518.

151. Selmi C, Tsuneyama K. Nutrition, geoepidemiology, and autoimmunity. Autoimmun Rev. 2010;9(5):A267-A270.

152. Procaccini C, Carbone F, Galgani M, et al. Obesity and susceptibility to autoimmune diseases. Expert Rev Clin Immunol. 2011;7(3):287-294.

153. Gardener H, Munger KL, Chitnis T, Michels KB, Spiegelman D, Ascherio A. Prenatal and perinatal factors and risk of multiple sclerosis. Epidemiology. 2009;20(4):611-618.

154. Munger KL, Chitnis T, Ascherio A. Body size and risk of MS in two cohorts of US women. Neurology. 2009;73(19):1543-1550.

155. Weinstock-Guttman B, Zivadinov R, Mahfooz N, et al. Serum lipid profiles are associated with disability and MRI outcomes in multiple sclerosis. J Neuroinflammation. 2011;8:127.

156. Matarese G, Carrieri PB, La Cava A, et al. Leptin increase in multiple sclerosis associates with reduced number of $\mathrm{CD} 4{ }^{+} \mathrm{CD} 25^{+}$regulatory T cells. Proc Natl Acad Sci U S A. 2005;102(14):5150-5155.

157. Campión J, Milagro FI, Martínez JA. Individuality and epigenetics in obesity. Obes Rev. 2009;10(4):383-392.

158. McLeod JG, Hammond SR, Hallpike JF. Epidemiology of multiple sclerosis in Australia. With NSW and SA survey results. Med J Aust. 1994;160(3):117-122.

159. Staples JA, Ponsonby AL, Lim LL, McMichael AJ. Ecologic analysis of some immune-related disorders, including type 1 diabetes, in Australia: latitude, regional ultraviolet radiation, and disease prevalence. Environ Health Perspect. 2003;111(4):518-523. 
160. Alamanos Y, Voulgari PV, Drosos AA. Incidence and prevalence of rheumatoid arthritis, based on the 1987 American College of Rheumatology criteria: a systematic review. Semin Arthritis Rheum. 2006;36(3):182-188.

161. Hengstman GJ, van Venrooij WJ, Vencovsky J, Moutsopoulos HM, van Engelen BG. The relative prevalence of dermatomyositis and polymyositis in Europe exhibits a latitudinal gradient. Ann Rheum Dis. 2000;59(2):141-142.

162. Beretich BD, Beretich TM. Explaining multiple sclerosis prevalence by ultraviolet exposure: a geospatial analysis. Mult Scler. 2009;15(8):891-898.

163. Becklund BR, Severson KS, Vang SV, DeLuca HF. UV radiation suppresses experimental autoimmune encephalomyelitis independent of vitamin D production. Proc Natl Acad Sci U S A. 2010;107(14):6418-6423.

164. Dong Z, Bode AM. The role of histone H3 phosphorylation (Ser10 and Ser28) in cell growth and cell transformation. Mol Carcinog. 2006;45(6):416-421.

165. Staibano S, Mascolo M, Siano M, Ilardi G, De Rosa G. Genetic, epigenetic and molecular changes in melanoma: a new paradigm for biological classification. In: Murph M, editor. Research on Melanoma: A Glimpse into Current Directions and Future Trends. Rijeka: InTech; 2011:35-68. Available from: http://www.intechopen.com/books/ research-on-melanoma-a-glimpse-into-current-directions-and-futuretrends/genetic-epigenetic-and-molecular-changes-in-melanoma-anew-paradigm-for-biological-classification. Accessed July 13, 2012.

166. Hall HI, May DS, Lew RA, Koh HK, Nadel M. Sun protection behaviors of the US white population. Prev Med. 1997;26(4):401-407.

167. Thomas-Ahner JM, Wulff BC, Tober KL, Kusewitt DF, Riggenbach JA, Oberyszyn TM. Gender differences in UVB-induced skin carcinogenesis, inflammation, and DNA damage. Cancer Res. 2007;67(7):3468-3474.

168. Karlic H, Varga F. Impact of vitamin D metabolism on clinical epigenetics. Clin Epigenetics. 2011;2(1):55-61.

169. Song Y, Fleet JC. 1,25 dihydroxycholecalciferol-mediated calcium absorption and gene expression are higher in female than in male mice. J Nutr. 2004;134(8):1857-1861.

170. Kragt J, van Amerongen B, Killestein J, et al. Higher levels of 25-hydroxyvitamin D are associated with a lower incidence of multiple sclerosis only in women. Mult Scler. 2009;15(1):9-15.

171. Bigazzi PE. Autoimmunity and heavy metals. Lupus. 1994;3(6): 449-453.

172. Hemdan NYA, Emmrich F, Faber S, Lehmann J, Sack U. Alterations of Th1/Th2 reactivity by heavy metals possible consequences include induction of autoimmune diseases. Ann N Y Acad Sci. 2007;1109: 129-137.

173. Hou L, Zhang X, Wang D, Baccarelli A. Environmental chemical exposures and human epigenetics. Int J Epidemiol. 2011;41(1):79-105.

174. Martinez-Zamudio R, Ha HC. Environmental epigenetics in metal exposure. Epigenetics. 2011;6(7):820-827.

175. Arnson Y, Shoenfeld Y, Amital H. Effects of tobacco smoke on immunity, inflammation and autoimmunity. JAutoimmun. 2010;34(3): J258-J265.

176. Suter M, Ma J, Harris AS, et al. Maternal tobacco use modestly alters correlated epigenome-wide placental DNA methylation and gene expression. Epigenetics. 2011;6(11):1284-1294.

177. Yung RL, Richardson BC. Drug-induced lupus. Rheum Dis Clin North Am. 1994;20(1):61-86.

178. Lee BH, Yegnasubramanian S, Lin X, Nelson WG. Procainamide is a specific inhibitor of DNA methyltransferase 1. J Biol Chem. 2005;280(49):40749-40756.

179. Gorelik G, Fang JY, Wu A, Sawalha AH, Richardson B. Impaired $\mathrm{T}$ cell protein kinase $\mathrm{C}$ delta activation decreases ERK pathway signaling in idiopathic and hydralazine-induced lupus. J Immunol. 2007;179(8):5553-5563.

180. Rieger R, Leung PS, Jeddeloh MR, et al. Identification of 2-nonynoic acid, a cosmetic component, as a potential trigger of primary biliary cirrhosis. J Autoimmun. 2006;27(1):7-16.
181. Prins GS. Estrogen imprinting: when your epigenetic memories come back to haunt you. Endocrinology. 2008;149(12):5919-5921.

182. Guerrero-Bosagna C, Sabat P, Valladares L. Environmental signaling and evolutionary change: can exposure of pregnant mammals to environmental estrogens lead to epigenetically induced evolutionary changes in embryos? Evol Dev. 2005;7(4):341-350.

183. Dolinoy DC, Weidman JR, Waterland RA, Jirtle RL. Maternal genistein alters coat color and protects Avy mouse offspring from obesity by modifying the fetal epigenome. Environ Health Perspect. 2006;114(4):567-572.

184. Strohsnitter WC, Noller KL, Troisi R, et al. Autoimmune disease incidence among women prenatally exposed to Diethylstilbestrol. J Rheumatol. 2010;37(10):2167-2173.

185. Campesi I, Sanna M, Zinellu A, et al. Oral contraceptives modify DNA methylation and monocyte-derived macrophage function. Biol Sex Differ. 2012;3:4

186. Hellwig K, Schimrigk S, Beste C, Muller T, Gold R. Increase in relapse rate during assisted reproduction technique in patients with multiple sclerosis. Eur Neurol. 2009;61(2):65-68.

187. Katari S, Turan N, Bibikova M, et al. DNA methylation and gene expression differences in children conceived in vitro or in vivo. Hum Mol Genet. 2009;18(20):3769-3778.

188. van Montfoort AP, Hanssen LL, de Sutter P, Viville S, Geraedts JP, de Boer P. Assisted reproduction treatment and epigenetic inheritance. Hum Reprod Update. 2012;18(2):171-197.

189. Krieg AM, Gourley MF, Perl A. Endogenous retroviruses: potential etiologic agents in autoimmunity. FASEB J. 1992;6(8): 2537-2544.

190. Nakkuntod J, Avihingsanon Y, Mutirangura A, Hirankarn N. Hypomethylation of LINE-1 but not Alu in lymphocyte subsets of systemic lupus erythematosus patients. Clin Chim Acta. 2011;412(15-16):1457-1461.

191. Issa JP, Ottaviano YL, Celano P, Hamilton SR, Davidson NE, Baylin SB. Methylation of the oestrogen receptor $\mathrm{CpG}$ island links ageing and neoplasia in human colon. Nat Genet. 1994;7(4):536-540.

192. Sarg B, Koutzamani E, Helliger W, Rundquist I, Lindner HH. Postsynthetic trimethylation of histone $\mathrm{H} 4$ at lysine 20 in mammalian tissues is associated with aging. J Biol Chem. 2002;277(42):39195-39201.

193. Fraga MF, Ballestar E, Paz MF, et al. Epigenetic differences arise during the lifetime of monozygotic twins. Proc Natl Acad Sci USA. 2005;102(30):10604-10609.

194. Bell JT, Tsai PC, Yang TP, et al. Epigenome-wide scans identify differentially methylated regions for age and age-related phenotypes in a healthy ageing population. PLoS Genet. 2012;8(4):e1002629.

195. Rakyan VK, Down TA, Maslau S, et al. Human aging-associated DNA hypermethylation occurs preferentially at bivalent chromatin domains. Genome Res. 2010;20(4):434-439.

196. Bernstein BE, Mikkelsen TS, Xie X, et al. A bivalent chromatin structure marks key developmental genes in embryonic stem cells. Cell. 2006;125(2):315-326.

197. Teschendorff AE, Menon U, Gentry-Maharaj A, et al. Age-dependent DNA methylation of genes that are suppressed in stem cells is a hallmark of cancer. Genome Res. 2010;20(4):440-446.

198. Javierre BM, Hernando H, Ballestar E. Environmental triggers and epigenetic deregulation in autoimmune disease. Discov Med. 2011;12(67):535-545.

199. Essex MJ, Thomas Boyce W, Hertzman C, et al. Epigenetic vestiges of early developmental adversity: childhood stress exposure and DNA methylation in adolescence. Child Dev. 2011. Epub Sep 2.

200. Weaver IC, Cervoni N, Champagne FA, et al. Epigenetic programming by maternal behavior. Nat Neurosci. 2004;7(8):847-854.

201. McCarthy MM, Auger AP, Bale TL, et al. The epigenetics of sex differences in the brain. J Neurosci. 2009;29(41):12815-12823.

202. Best JD, Carey N. The epigenetics of normal pregnancy. Obstet Med. 2011. Epub Dec 15.

203. D'hooghe MB, Nagels G, Uitdehaag BM. Long-term effects of childbirth in MS. J Neurol Neurosurg Psychiatry. 2010;81(1):38-41. 
204. Runmarker B, Andersen O. Pregnancy is associated with a lower risk of onset and a better prognosis in multiple sclerosis. Brain. 1995; 118(Pt 1):253-261.

205. Verdru P, Theys P, D'Hooghe MB, Carton H. Pregnancy and multiple sclerosis: the influence on long term disability. Clinical Neurol Neurosurg. 1994;96(1):38-41.

206. Gleeson M, Bishop NC, Stensel DJ, Lindley MR, Mastana SS, Nimmo MA. The anti-inflammatory effects of exercise: mechanisms and implications for the prevention and treatment of disease. Nat Rev Immunol. 2011;11(9):607-615.

207. Dalgas U, Stenager E. Exercise and disease progression in multiple sclerosis: can exercise slow down the progression of multiple sclerosis? Ther Adv Neurol Disord. 2012;5(2):81-95.

208. Barrès R, Yan J, Egan B, et al. Acute exercise remodels promoter methylation in human skeletal muscle. Cell Metab. 2012;15(3):405-411.

209. McGee SL, Fairlie E, Garnham AP, Hargreaves M. Exercise-induced histone modifications in human skeletal muscle. J Physiol. 2009; 587(Pt 24):5951-5958.

210. Ballestar E, Esteller M, Richardson BC. The epigenetic face of systemic lupus erythematosus. J Immunol. 2006;176(12):7143-7147.

211. Lu Q, Wu A, Tesmer L, Ray D, Yousif N, Richardson B. Demethylation of CD40 LG on the inactive $\mathrm{X}$ in T cells from women with lupus. $J$ Immunol. 2007;179(9):6352-6358.

212. Alves NL, Arosa FA, van Lier RA. Common gamma chain cytokines: dissidence in the details. Immunol Lett. 2007;108(2):113-120.

213. Bennett CL, Christie J, Ramsdell F, et al. The immune dysregulation, polyendocrinopathy, enteropathy, X-linked syndrome (IPEX) is caused by mutations of FOXP3. Nat Genet. 2001;27(1):20-21.

214. Spurr NK, Goodfellow PN, Docherty AJ. Chromosomal assignment of the gene encoding the human tissue inhibitor of metalloproteinases to Xp11.1-p11.4. Ann Hum Genet. 1987;51(Pt 3):189-194.

215. Zehntner SP, Bourbonnière L, Moore CS, et al. X-linked inhibitor of apoptosis regulates T cell effector function. J Immunol. 2007; 179(11):7553-7560.

216. Møller-Larsen S, Nyegaard M, Haagerup A, Vestbo J, Kruse TA, Børglum AD. Association analysis identifies TLR7 and TLR8 as novel risk genes in asthma and related disorders. Thorax. 2008;63(12):1064-1069.

217. Chitnis S, Monteiro J, Glass D, et al. The role of X-chromosome inactivation in female predisposition to autoimmunity. Arthritis Res 2000;2(5):399-406.

218. Brix TH, Knudsen GP, Kristiansen M, Kyvik KO, Orstavik KH, Hegedüs L. High frequency of skewed X-chromosome inactivation in females with autoimmune thyroid disease: a possible explanation for the female predisposition to thyroid autoimmunity. J Clin Endocrinol Metab. 2005;90(11):5949-5953.

219. Ozcelik T, Uz E, Akyerli CB, et al. Evidence from autoimmune thyroiditis of skewed $\mathrm{X}$-chromosome inactivation in female predisposition to autoimmunity. Eur J Hum Genet. 2006;14(6):791-797.

220. Ozbalkan Z, Bagişlar S, Kiraz S, et al. Skewed X chromosome inactivation in blood cells of women with scleroderma. Arthritis Rheum. 2005;52(5):1564-1570.

221. Huang Q, Parfitt A, Grennan DM, Manolios N. X-chromosome inactivation in monozygotic twins with systemic lupus erythematosus. Autoimmunity. 1997;26(2):85-93.

222. Knudsen GP. Gender bias in autoimmune diseases: X chromosome inactivation in women with multiple sclerosis. J Neurol Sci. 2009;286(1-2):43-46.

223. Boyle AP, Davis S, Shulha HP, et al. High-resolution mapping and characterization of open chromatin across the genome. Cell. 2008; 132(2):311-322.

224. Hesselberth JR, Chen X, Zhang Z, et al. Global mapping of proteinDNA interactions in vivo by digital genomic footprinting. Nat Methods. 2009;6(4):283-289.

225. Park PJ. ChIP-seq: advantages and challenges of a maturing technology. Nat Rev Genet. 2009;10(10):669-680.

226. Laird PW. Principles and challenges of genomewide DNA methylation analysis. Nat Rev Genet. 2010;11(3):191-203.
227. Birney E. Chromatin and heritability: how epigenetic studies can complement genetic approaches. Trends Genet. 2011;27(5):172-176.

228. Barski A, Cuddapah S, Cui K, et al. High-resolution profiling of histone methylations in the human genome. Cell. 2007;129(4):823-837.

229. Campos EI, Reinberg D. Histones: annotating chromatin. Ann Rev Genet. 2009;43:559-599.

230. Koch CM, Andrews RM, Flicek P, et al. The landscape of histone modifications across $1 \%$ of the human genome in five human cell lines. Genome Res. 2007;17(6):691-707.

231. Rosenfeld JA, Wang Z, Schones DE, Zhao K, DeSalle R, Zhang MQ. Determination of enriched histone modifications in non-genic portions of the human genome. BMC Genomics. 2009;10:143.

232. Zhou VW, Goren A, Bernstein BE. Charting histone modifications and the functional organization of mammalian genomes. Nat Rev Genet. 2011;12(1):7-18.

233. Lennartsson A, Ekwall K. Histone modification patterns and epigenetic codes. Biochim Biophys Acta. 2009;1790(9):863-868.

234. Huff JT, Plocik AM, Guthrie C, Yamamoto KR. Reciprocal intronic and exonic histone modification regions in humans. Nat Struct Mol Biol. 2010;17(12):1495-1499.

235. Hirst C, Ingram G, Pickersgill T, Swingler R, Compston DA, Robertson NP. Increasing prevalence and incidence of multiple sclerosis in South East Wales. J Neurol Neurosurg Psychiatry. 2009;80(4):386-391.

236. Weinshenker BG, Bass B, Rice GP, et al. The natural history of multiple sclerosis: a geographically based study. I. Clinical course and disability. Brain. 1989;112(Pt 1):133-146.

237. Ebers GC, Bulman DE, Sadovnick AD, et al. A population-based study of multiple sclerosis in twins. N Engl J Med. 1986;315(26):1638-1642.

238. Willer CJ, Dyment DA, Risch NJ, Sadovnick AD, Ebers GC; The Canadian Collaborative Study Group. Twin concordance and sibling recurrence rates in multiple sclerosis. Proc Natl Acad Sci U S A. 2003;100(22):12877-12882.

239. Hansen T, Skytthe A, Stenager E, Petersen HC, Brønnum-Hansen H, Kyvik KO. Concordance for multiple sclerosis in Danish twins: an update of a nationwide study. Mult Scler. 2005;11(5):504-510.

240. Kuusisto H, Kaprio J, Kinnunen E, Luukkaala T, Koskenvuo M, Elovaara I. Concordance and heritability of multiple sclerosis in Finland: study on a nationwide series of twins. Eur J Neurol. 2008;15(10): 1106-1110.

241. Ostman J, Lonnberg G, Arnqvist HJ, et al. Gender differences and temporal variation in the incidence of type 1 diabetes: results of 8012 cases in the nationwide Diabetes Incidence Study in Sweden 1983-2002. J Intern Med. 2008;263(4):386-394.

242. Eaton WW, Rose NR, Kalaydjian A, Pedersen MG, Mortensen PB. Epidemiology of autoimmune diseases in Denmark. J Autoimmun. 2007;29(1):1-9.

243. Kaprio J, Tuomilehto J, Koskenvuo M, et al. Concordance for type 1 (insulin-dependent) and type 2 (non-insulin-dependent) diabetes mellitus in a population-based cohort of twins in Finland. Diabetologia. 1992;35(11):1060-1067.

244. Metcalfe KA, Hitman GA, Rowe RE, et al. Concordance for type 1 diabetes in identical twins is affected by insulin genotype. Diabetes Care. 2001;24(5):838-842.

245. Kyvik KO, Green A, Beck-Nielsen H. Concordance rates of insulin dependent diabetes mellitus: a population based study of young Danish twins. BMJ. 1995;311(7010):913-917.

246. McCarty DJ, Manzi S, Medsger TA Jr, Ramsey-Goldman R, LaPorte RE, Kwoh CK. Incidence of systemic lupus erythematosus. Race and gender differences. Arthritis Rheum. 1995;38(9):1260-1270.

247. Deapen D, Escalante A, Weinrib L, et al. A revised estimate of twin concordance in systemic lupus erythematosus. Arthritis Rheum. 1992;35(3):311-318.

248. Järvinen P, Kaprio J, Mäkitalo R, Koskenvuo M, Aho K. Systemic lupus erythematosus and related systemic diseases in a nationwide twin cohort: an increased prevalence of disease in MZ twins and concordance of disease features. J Intern Med. 1992;231(1):67-72.

249. Grennan DM, Parfitt A, Manolios N, et al. Family and twin studies in systemic lupus erythematosus. Dis Markers. 1997;13(2):93-98. 
250. Gonzalez A, Maradit Kremers H, Crowson CS, et al. The widening mortality gap between rheumatoid arthritis patients and the general population. Arthritis Rheum. 2007;56(11):3583-3587.

251. Winchester RJ. Genetic aspects of rheumatoid arthritis. Springer Semin Immunopathol. 1981;4(2):89-102.

252. Aho K, Koskenvuo M, Tuominen J, Kaprio J. Occurrence of rheumatoid arthritis in a nationwide series of twins. $J$ Rheumatol. 1986;13(5):899-902.

253. Silman AJ, MacGregor AJ, Thomson W, et al. Twin concordance rates for rheumatoid arthritis: results from a nationwide study. $\mathrm{Br} J$ Rheumatol. 1993;32(10):903-907.

254. Krassas GE, Tziomalos K, Pontikides N, Lewy H, Laron Z. Seasonality of month of birth of patients with Graves' and Hashimoto's diseases differ from that in the general population. Eur J Endocrinol. 2007;156(6):631-636.

255. Brix TH, Kyvik KO, Christensen K, Hegedüs L. Evidence for a major role of heredity in Graves' disease: a population-based study of two Danish twin cohorts. J Clin Endocrinol Metab. 2001;86(2): 930-934.

256. Ringold DA, Nicoloff JT, Kesler M, Davis H, Hamilton A, Mack T. Further evidence for a strong genetic influence on the development of autoimmune thyroid disease: the California twin study. Thyroid. 2002;12(8):647-653

257. Kaplan MM, Gershwin ME. Primary biliary cirrhosis. N Engl J Med. 2005;353(12):1261-1273

258. Selmi C, Mayo MJ, Bach N, et al. Primary biliary cirrhosis in monozygotic and dizygotic twins: genetics, epigenetics, and environment. Gastroenterology. 2004;127(2):485-492.

259. Naldi L, Chatenoud L, Belloni A, et al. Medical history, drug exposure and the risk of psoriasis. Evidence from an Italian case-control study. Dermatology. 2008;216(2):125-130.

260. Duffy DL, Spelman LS, Martin NG. Psoriasis in Australian twins. J Am Acad Dermatol. 1993;29(3):428-434.

261. Krueger GG, Duvic M. Epidemiology of psoriasis: clinical issues. $J$ Invest Dermatol. 1994;102(6):14S-18S.

262. Mantegazza R, Baggi F, Antozzi C, et al. Myasthenia gravis (MG): epidemiological data and prognostic factors. Ann N Y Acad Sci. 2003;998:413-423.

263. Ramanujam R, Pirskanen R, Ramanujam S, Hammarström L. Utilizing twins concordance rates to infer the predisposition to myasthenia gravis. Twin Res Hum Genet. 2011;14(2):129-136.

264. Will R, Edmunds L, Elswood J, Calin A. Is there sexual inequality in ankylosing spondylitis? A study of 498 women and 1202 men. J Rheumatol. 1990;17(12):1649-1652.

265. Pedersen OB, Svendsen AJ, Ejstrup L, Skytthe A, Harris JR, Junker P. Ankylosing spondylitis in Danish and Norwegian twins: occurrence and the relative importance of genetic vs environmental effectors in disease causation. Scand J Rheumatol. 2008;37(2): $120-126$

266. Balada E, Ordi-Ros J, Vilardell-Tarrés M. DNA methylation and systemic lupus erythematosus. Ann N Y Acad Sci. 2007;1108: 127-136.

267. Renaudineau Y, Youinou P. Epigenetics and autoimmunity, with special emphasis on methylation. Keio J Med. 2011;60(1):10-16.

268. Zouali M. Epigenetics in lupus. Ann N Y Acad Sci. 2011;1217: 154-165.

269. Garaud S, Le Dantec C, Jousse-Joulin S, et al. IL-6 modulates CD5 expression in B cells from patients with lupus by regulating DNA methylation. J Immunol. 2009;182(9): 5623-5632.

270. Pauley KM, Satoh M, Chan AL, Bubb MR, Reeves WH, Chan EK. Upregulated miR-146a expression in peripheral blood mononuclear cells from rheumatoid arthritis patients. Arthritis Res Ther. 2008;10(4):R101.

271. Hu N, Qiu X, Luo Y, et al. Abnormal histone modification patterns in lupus CD4+ T cells. J Rheumatol. 2008;35(5):804-810.
272. Luo Y, Li Y, Su Y, et al. Abnormal DNA methylation in T cells from patients with subacute cutaneous lupus erythematosus. BrJ Dermatol. 2008;159(4):827-833.

273. Lei W, Luo Y, Lei W, et al. Abnormal DNA methylation in CD4+T cells from patients with systemic lupus erythematosus, systemic sclerosis, and dermatomyositis. Scand J Rheumatol. 2009;38(5):369-374.

274. Sunahori K, Juang YT, Kyttaris VC, Tsokos GC. Promoter hypomethylation results in increased expression of protein phosphatase $2 \mathrm{~A}$ in $\mathrm{T}$ cells from patients with systemic lupus erythematosus. $J$ Immunol. 2011;186(7):4508-4517.

275. Januchowski R, Wudarski M, Chwalińska-Sadowska H, Jagodzinski PP. Prevalence of ZAP-70, LAT, SLP-76, and DNA methyltransferase 1 expression in CD4+ T cells of patients with systemic lupus erythematosus. Clin Rheumatol. 2008;27(1):21-27.

276. Yin $\mathrm{H}, \mathrm{Zhao} \mathrm{M}, \mathrm{Wu} \mathrm{X}$, et al. Hypomethylation and overexpression of CD70 (TNFSF7) in CD4+ T cells of patients with primary Sjögren's syndrome. J Dermatol Sci. 2010;59(3):198-203.

277. Jiang H, Xiao R, Lian X, et al. Demethylation of TNFSF7 contributes to CD70 overexpression in CD4+ T cells from patients with systemic sclerosis. Clin Immunol. 2012;143(1):39-44.

278. Liu Y, Chen Y, Richardson B. Decreased DNA methyltransferase levels contribute to abnormal gene expression in "senescent" CD4(+) CD28(-) T cells. Clin Immunol. 2009;132(2):257-265.

279. Fulci V, Scappucci G, Sebastiani GD, et al. miR-223 is overexpressed in T-lymphocytes of patients affected by rheumatoid arthritis. Hum Immunol. 2010;71(2):206-211.

280. Janson PC, Linton LB, Bergman EA, et al. Profiling of CD4+ T Cells with epigenetic immune lineage analysis. J Immunol. 2011; 186(1):92-102.

281. Junker A. Pathophysiology of translational regulation by microRNAs in multiple sclerosis. FEBS Letters. 2011;585(23):3738-3746.

282. Lleo A, Liao J, Invernizzi P, et al. Immunoglobulin M levels inversely correlate with CD40 ligand promoter methylation in patients with primary biliary cirrhosis. Hepatology. 2012;55(1):153-160.

283. Lu Q, Wu A, Ray D, et al. DNA methylation and chromatin structure regulate $\mathrm{T}$ cell perforin gene expression. J Immunol. 2003; 170(10):5124-5132.

284. Dai Y, Huang YS, Tang M, et al. Microarray analysis of microRNA expression in peripheral blood cells of systemic lupus erythematosus patients. Lupus. 2007;16(12):939-946.

285. Miao F, Smith DD, Zhang L, Min A, Feng W, Natarajan R. Lymphocytes from patients with type 1 diabetes display a distinct profile of chromatin histone $\mathrm{H} 3$ lysine 9 dimethylation: an epigenetic study in diabetes. Diabetes. 2008;57(12):3189-3198.

286. van Bavel CC, Dieker J, Muller S, et al. Apoptosis-associated acetylation on histone H2B is an epitope for lupus autoantibodies. Mol Immunol. 2009;47(2-3):511-516.

287. Nakasa T, Miyaki S, Okubo A, et al. Expression of microRNA146 in rheumatoid arthritis synovial tissue. Arthritis Rheum. 2008;58(5):1284-1292.

288. Stanczyk J, Ospelt C, Karouzakis E, et al. Altered expression of microRNA-203 in rheumatoid arthritis synovial fibroblasts and its role in fibroblast activation. Arthritis Rheum. 2011;63(2):373-381.

289. Takami N, Osawa K, Miura Y, et al. Hypermethylated promoter region of DR3, the death receptor 3 gene, in rheumatoid arthritis synovial cells. Arthritis Rheum. 2006;54(3):779-787.

290. Sánchez-Pernaute O, Ospelt C, Neidhart M, Gay S. Epigenetic clues to rheumatoid arthritis. J Autoimmun. 2008;30(1-2):12-20.

291. Padgett KA, Lan RY, Leung PC, et al. Primary biliary cirrhosis is associated with altered hepatic microRNA expression. J Autoimmun. 2009;32(3-4):246-253.

292. Alevizos I, Illei GG. MicroRNAs in Sjögren's syndrome as a prototypic autoimmune disease. Autoimmun Rev. 2010;9(9):618-621.

293. Joyce CE, Zhou X, Xia J, et al. Deep sequencing of small RNAs from human skin reveals major alterations in the psoriasis miRNAome. Hum Mol Genet. 2011;20(20):4025-4040. 
294. Roberson ED, Liu Y, Ryan C, et al. A subset of methylated CpG sites differentiate psoriatic from normal skin. J Invest Dermatol. 2012; 132(3 Pt 1):583-592.

295. Ruchusatsawat K, Wongpiyabovorn J, Shuangshoti S, Hirankarn N, Mutirangura A. SHP-1 promoter 2 methylation in normal epithelial tissues and demethylation in psoriasis. J Mol Med (Berl). 2006;84(2): $175-182$.

296. Huynh JL, Casaccia P. Defining the chromatin landscape in demyelinating disorders. Neurobiol Dis. 2010;39(1):47-52.
297. Kubo M, Czuwara-Ladykowska J, Moussa O, et al. Persistent downregulation of Fli1, a suppressor of collagen transcription, in fibrotic scleroderma skin. Am J Pathol. 2003;163(2):571-581.

298. Luger K, Mäder AW, Richmond RK, Sargent DF, Richmond TJ. Crystal structure of the nucleosome core particle at $2.8 \mathrm{~A}$ resolution. Nature. 1997;389(6648):251-260.

\section{Publish your work in this journal}

Biologics: Targets \& Therapy is an international, peer-reviewed journal focusing on the patho-physiological rationale for and clinical application of Biologic agents in the management of autoimmune diseases, cancers or other pathologies where a molecular target can be identified. This journal is indexed on PubMed Central, CAS, EMBase, Scopus

\section{Dovepress}

and the Elsevier Bibliographic databases. The manuscript management system is completely online and includes a very quick and fair peerreview system, which is all easy to use. Visit http://www.dovepress. com/testimonials.php to read real quotes from published authors.

Submit your manuscript here: http://www.dovepress.com/biologics-targets--therapy-journal 